Rev. Int. Contam. Ambie. 35 (4) 849-868, 2019

DOI: 10.20937/RICA.2019.35.04.07

\title{
ASSESSMENT OF A SIMPLE EXTRACTION METHOD TO DETERMINE THE BIOACCESSIBILITY OF POTENTIALLY TOXIC Tl, As, Pb, Cu, Zn AND Cd IN SOILS CONTAMINATED BY MINING-METALLURGICAL WASTE
}

\author{
Evaluación de un método de extracción simple para determinar la bioaccesibilidad de $\mathrm{Tl}, \mathrm{As}, \mathrm{Pb}, \mathrm{Cu}, \mathrm{Zn}$ y $\mathrm{Cd}$ \\ potencialmente tóxicos en suelos contaminados por residuos minero-metalúrgicos
}

\begin{abstract}
Yusniel CRUZ-HERNÁNDEZ ${ }^{1,2 *}$, Alicia SANTANA-SILVA ${ }^{1}$, Mario VILLALOBOS $^{1}$, Francisco ROMERO ${ }^{1}$, Elizabeth HERNÁNDEZ-ÁLVAREZ ${ }^{3}$ and Teresa PI-PUIG ${ }^{4}$
\end{abstract}

${ }^{1}$ Laboratorio de Geoquímica Ambiental, Laboratorio Nacional de Geoquímica y Mineralogía (LANGEM), Instituto de Geología, Universidad Nacional Autónoma de México, Ciudad Universitaria, 04510, Ciudad de México, México.

${ }^{2}$ Department of Civil and Environmental Engineering, University of Connecticut, Storrs, Connecticut 06269 , United States.

${ }^{3}$ Laboratorio de ICP-MS, Instituto de Geofísica, Universidad Nacional Autónoma de México, Ciudad Universitaria, 04510, Ciudad de México, México.

${ }^{4}$ Laboratorio de DRX, Instituto de Geología, Universidad Nacional Autónoma de México, Ciudad Universitaria, 04510, Ciudad de México, México.

*Corresponding author: yusniel.cruz_hernandez@uconn.edu

(Received: October 2018; accepted: January 2019)

Key words: $\mathrm{HCl}, \mathrm{SBRC}, \mathrm{pH}$, mining residues, speciation

\begin{abstract}
The potential to determine the gastric bioaccessibility (BA) of Tl, As, $\mathrm{Pb}(\mathrm{II}), \mathrm{Cu}(\mathrm{II})$, $\mathrm{Zn}(\mathrm{II})$ and $\mathrm{Cd}(\mathrm{II})$ using a simple extraction method was evaluated in selected samples from soils contaminated by mining and metallurgical wastes. The SBRC (Solubility and Bioavailability Research Consortium) test was used as a gastric BA comparative method versus a simple extraction method using $\mathrm{HCl}$ solution at $\mathrm{pH}$ 1.5. High correlations $(r \geq 0.98, p<0.01)$ were obtained between the two extraction methods for $\mathrm{Cd}(\mathrm{II}), \mathrm{Cu}(\mathrm{II}), \mathrm{Tl}$ and $\mathrm{Zn}(\mathrm{II})$, in all samples investigated. Bioaccessible As, however, only showed a high correlation in the metallurgical area $(\mathrm{r}=0.99, \mathrm{p}<0.01)$, but not in the mining area $(\mathrm{r}=0.88, \mathrm{p}<0.01)$. Conversely, $\mathrm{Pb}(\mathrm{II})$ showed a better correlation in samples from the mining area $(r=0.99, p<0.01)$ than in those of the metallurgical area $(\mathrm{r}=0.92, \mathrm{p}<0.01)$. Three experimental conditions of the extraction procedures ensured the high correlations observed: (1) Maintaining a strict $\mathrm{pH}$ control of 1.5 $( \pm 0.1),(2)$ a stirring time of $1 \mathrm{~h}( \pm 1 \mathrm{~min})$, and (3) filtration of the extraction mixture through a membrane of small pore size $(0.05 \mu \mathrm{m})$. Bioaccessible $\mathrm{Tl}$ was detected in all samples, a fact that has not been reported before in these environments, and alerts to potential health risks not previously identified.
\end{abstract}

Palabras clave: $\mathrm{HCl}, \mathrm{SBRC}, \mathrm{pH}$, residuos mineros, especiación 


\title{
RESUMEN
}

\begin{abstract}
El potencial para determinar la bioaccesibilidad gástrica (BA) de Tl, As, $\mathrm{Pb}(\mathrm{II}), \mathrm{Cu}(\mathrm{II})$, $\mathrm{Zn}$ (II) y Cd(II) utilizando un método de extracción simple se evaluó en muestras seleccionadas de suelos contaminados por residuos mineros y metalúrgicos. La prueba SBRC (Consorcio de Investigación de Solubilidad y Biodisponibilidad) se usó como un método comparativo de BA gástrica versus un método de extracción simple que utiliza una solución de $\mathrm{HCl}$ a $\mathrm{pH}$ 1.5. Se obtuvieron altas correlaciones $(\mathrm{r} \geq 0.98$, $\mathrm{p}<0.01)$ entre los dos métodos de extracción para $\mathrm{Cd}(\mathrm{II}), \mathrm{Cu}(\mathrm{II}), \mathrm{Tl}$ y $\mathrm{Zn}(\mathrm{II})$, en todas las muestras investigadas. El arsénico bioaccesible, sin embargo, sólo mostró una alta correlación en el área metalúrgica $(\mathrm{r}=0.99, \mathrm{p}<0.01)$, pero no en el área minera $(\mathrm{r}=0.88, \mathrm{p}<0.01)$. Al contrario, el $\mathrm{Pb}(\mathrm{II})$ mostró una mejor correlación en las muestras del área minera $(\mathrm{r}=0.99, \mathrm{p}<0.01)$ que en las del área metalúrgica $(\mathrm{r}=0.92, \mathrm{p}<0.01)$. Tres condiciones experimentales de los procedimientos de extracción aseguraron las altas correlaciones observadas: (1) Mantener un control estricto del pH a $1.5( \pm 0.1),(2)$ un tiempo de agitación de $1 \mathrm{~h}$ ( $\pm 1 \mathrm{~min})$, y (3) filtración de la mezcla de extracción a través de una membrana de tamaño de poro pequeño $(0.05 \mu \mathrm{m})$. Se detectó T1 bioaccesible en todas las muestras, un hecho que no se había informado anteriormente en estos entornos y alerta sobre riesgos potenciales para la salud no identificados previamente.
\end{abstract}

\section{INTRODUCTION}

Soils contaminated with potentially toxic elements (PTEs) constitute a risk to human health and to biota. At low contents some PTEs, such as copper, chromium, molybdenum, selenium, and zinc are essential for the functioning of human health and for the growth of plants and animals. However, at higher contents they become toxic and cause adverse effects (Li et al. 2014, 2015). Other elements such as thallium, arsenic, cadmium, mercury and lead are toxic even at low contents (Mingot et al. 2011, Smith et al. 2011, Yang et al. 2015, Mendoza et al. 2017, Cui et al. 2018, Cruz-Hernández et al. 2018, Pelfrêne and Douay 2018).

A soil is considered contaminated with PTEs when their total contents exceed the natural background levels (SEMARNAT 2007). However, it is currently agreed upon that a real ecological risk occurs only when the elements are in bioavailable forms, i.e., when the chemical species present can enter living organisms and cause adverse health effects (Mendoza et al. 2017). The most bioavailable forms of PTEs are obviously the water-soluble chemical species because they can enter the organism directly through the consumption of polluted water. However, other less available chemical forms may also pose high threats to organisms because of the chemical reactions that occur upon their entry into or their interactions with the organisms (Santana-Silva 2016). The different chemical forms of PTEs depend on many factors and geochemical conditions, such as $\mathrm{pH}$, their mineralogical occurrence or associations, the environmental redox status, and the availability of complexing agents (Cruz-Hernández et al. 2018).
One route of exposure of environmental contaminants in humans and animals is by oral ingestion (Luo et al. 2012). Intake can occur through the consumption of soil directly or indirectly through vegetables, animals and drinking water that are contaminated by soil dust containing these elements, causing potentially harmful health effects (Li et al. 2016b, Fujimori et al. 2017). Soil intake is a major problem in communities that live in areas adjacent to miningmetallurgical wastes, because of the relatively high contents of PTEs.

The bioavailability (BV) of PTEs in soils is determined by different methods that involve feeding the living organisms of interest with the contaminated material, and then, at the appropriate times, sampling fluids or tissues from within the organisms, or from their excretions, such as urine. This makes the procedures quite costly, complicated, and cumbersome, and has prompted widespread attempts at simulating chemically (in vitro) as closely as possible the digestive processes that occur, in such a way as to obtain equal results to those in BV tests. A suite of simpler chemical-based (in vitro) extraction tests applicable to contaminated soils has emerged to simulate the BV process and have been called bioaccessibility (BA) tests (Ruby et al. 1999, Carrizales et al. 2006, Mendoza et al. 2017).

One of the most popular BA methods is the Solubility and Bioavailability Research Consortium (SBRC) test, originally devised to determine the BA of lead, but now extended to other PTEs. This test consists of simulating the extraction of contaminants in the gastric phase, at $\mathrm{pH}=1.5$, using a $0.04 \mathrm{M}$ glycine buffer (Drexler and Brattin 2007); it is the 
method adopted by the Official Mexican Standard NOM-147-SEMARNAT/SSA1-2004 (SEMARNAT 2007 ) to evaluate BA in contaminated soils.

The gastric SBRC BA test has proven to correlate highly with the BV measured in vivo (Drexler and Brattin 2007) and, therefore, it is this simpler method that is extremely useful to estimate with great accuracy the BV of several PTEs, which is too laborious and expensive and requires the sacrifice of living beings. However, since this BA test is still a complex method that requires equipment and reagents specifically designed for it, the goal of the present research was to determine if it is possible to perform an even simpler extraction test, applicable in a widespread manner in environmental analysis laboratories that could correlate strongly with this chosen reference $\mathrm{BA}$ test, considering $\mathrm{HCl}$ is the main extracting agent in the gastric phase.

Several simple extraction methods have been evaluated to determine the content of metals extracted from the soil and to estimate bioaccesibility and phytoavailability (Madrid et al. 2008, Cao et al. 2009, Rodrigues et al. 2013, Li et al. 2017). Inorganic acids have been used in urban soils, but have not been tested in those affected by mining-metallurgical activities [0.43 $\mathrm{M} \mathrm{HNO}_{3}$ (Rodrigues et al. 2013)], showing high correlations with the SBET method [Simple Bioaccessibility Extraction Test (Kim et al. 2002, USEPA 2008)], which consists of soil extractions with a $0.4 \mathrm{M}$ glycine solution adjusted to $\mathrm{pH}$ $1.50 \pm 0.05$ (with $\mathrm{HCl}$ ), for assessing the $\mathrm{BA}$ of $\mathrm{Cd}$, $\mathrm{Cu}, \mathrm{Pb}$, and $\mathrm{Zn}$ ) $[r$ values ranging from 0.97 (for $\mathrm{Cd}$ ) to 0.99 (for $\mathrm{Cu}, \mathrm{Pb}$ and $\mathrm{Zn}$ )]. As and $\mathrm{Tl}$ were not tested. Also organic acid and complexing agents have been used [acetic acid and EDTA (Waterlot et al. 2017)], yielding relatively good correlations ( $r>0.94)$ with the gastric and gastrointestinal phases. Neutral salts have been used as well $\left[\mathrm{CaCl}_{2}\right.$ (Rodrigues et al. 2013), $\mathrm{NaNO}_{3}$ (Pueyo et al. 2004), $\mathrm{MgCl}_{2}$ (Takeda et al. 2006)], yielding accurate results (normally $<10 \%$ ) for all metals ( $\mathrm{Cu}, \mathrm{Zn}, \mathrm{Pb}$ and $\mathrm{Cd}$ ), taking into account the low concentrations of metals extracted. The extraction efficiency of metals obtained with each salt was slightly different, and all three methods provided equivalent information, where the relative mobility of the trace metals $(\mathrm{Cd}>\mathrm{Zn}>\mathrm{Cu}>\mathrm{Pb})$ was correctly predicted in the studied soils.

Mingot et al. (2011) evaluated three extraction methods to determine the bioaccessibility of As in soils of a recreational area in Madrid. The methods used were PBET, SBRC and $\mathrm{HCl}$-extraction. The extraction conditions with $\mathrm{HCl}$ were at a temperature of $37^{\circ} \mathrm{C}$, under stirring for one hour with a concentra- tion of $0.07 \mathrm{M} \mathrm{HCl}$ and a sample mass $(\mathrm{g})$ to volume $(\mathrm{mL})$ ratio of 1: 1000. In this study, a relatively low correlation $(r=0.776)$ was found between the SBRC method and $\mathrm{HCl}$ for the extraction of As.

Dodd et al. (2013) determined bioaccesibility in dust samples and soil standards. Gastric BA was evaluated using the SBRC test and a modification of the EN-71 protocol (European Standard Toy Safety Protocol EN-71, European Commitee for Standarization 1995$)\left(0.07 \mathrm{M} \mathrm{HCl}\right.$ solution at $37^{\circ} \mathrm{C}$, stirring for two hours, a sample mass $(\mathrm{g})$ to volume $(\mathrm{mL})$ ratio of 1: 2000, which is the key modification of the EN-71 Toy Safety protocol). Correlation coefficients between the SBRC test and the modified protocol EN-71 for As, $\mathrm{Cd}, \mathrm{Cu}, \mathrm{Pb}, \mathrm{Ni}$ and $\mathrm{Zn}$, ranged between 0.85 and 0.92 .

In the present work we evaluated a simple extraction method using $\mathrm{HCl}$ at a fixed $\mathrm{pH}$ of 1.5 and compared it to the gastric SBRC BA method for Tl, $\mathrm{As}, \mathrm{Pb}, \mathrm{Zn}, \mathrm{Cu}$ and $\mathrm{Cd}$ in a series of samples originating from mining wastes and from soils contaminated with metallurgical wastes, from two selected areas of Mexico. The goal was to investigate the possibility of improving considerably the correlations found from past reports by carefully controlling the following experimental parameters: the soil: solution ratio and stirring time, $\mathrm{pH}$, a very small pore size of the filtration membrane, and the temperature. Although the composition of the human gastrointestinal tract is complex, the primary component from the point of view of PTE extraction is $\mathrm{HCl}$ and, therefore, simple extractions with $\mathrm{HCl}$ may strongly correlate with those of the SBRC method at the same $\mathrm{pH}$ value and controlled experimental conditions that ensure measuring only dissolved concentrations (which in turn correlates quite well with BV values). The specific PTE speciation was not discussed or analyzed, except in the few cases where important differences were found between the two methods.

\section{MATERIALS AND METHODS}

\section{Study area and sample collection}

The areas studied in Mexico correspond to the North-Center of the country: Metallurgical District of "San Luis Potosí" (SLP) (Fig. 1a), and the SouthCenter: soils and mine tailings of the "Taxco" (TX) mining area in the state of Guerrero (Fig. $1 \mathbf{b}$ and c). Nine superficial samples were analyzed from the old SLP copper and arsenic plants, and 18 samples of six mine tailings vertical profiles and four superficial soil samples contaminated by such tailings from TX. The TX samples came from three tailings impoundments, 


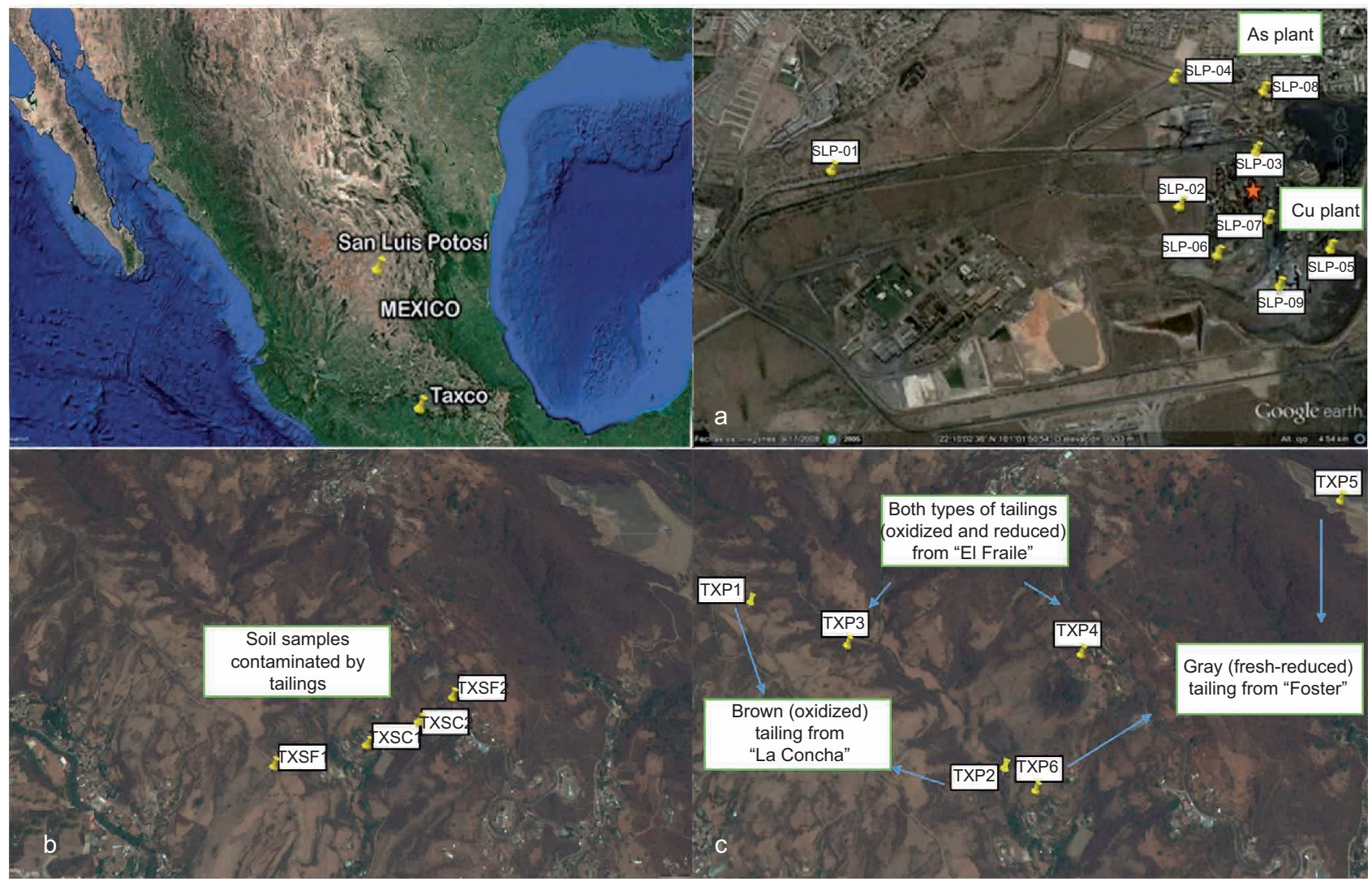

Fig. 1. Google Earth images of San Luis Potosí and Taxco study areas showing the locations of mining wastes, soils and metallurgical residues collected from a) San Luis Potosí metallurgical plant, b) Taxco soils, and c) Taxco mine tailings

which correspond to different degrees of oxidation: aged (oxidized) tailings from "La Concha" showed brown colors, and fresh (reduced) tailings from "Foster" showed a gray color; while tailings from "El Fraile" showed both types of tailings. Table SI (Supporting Information) summarizes the location and description of the selected samples.

Approximately two kilograms of sample were collected for each sampling point, by simple random sampling (USEPA 1993). In the laboratory, all samples were dried at $40{ }^{\circ} \mathrm{C}$ for $72 \mathrm{~h}$ after weakly dispersing the soils horizontally in trays, then homogenized, sieved (2 $\mathrm{mm}$ mesh) and transferred to plastic bags prior to analysis.

The metallurgical study area is located in the western part of the city of San Luis Potosí in NorthCentral Mexico. Mining activities in this area began in April 1892. Three metallurgical plants that produced copper, arsenic and lead operated on this site. When the metallurgical activities began, this site was not populated, but with the passage of time towns adjacent to the site began to develop. There is currently a residential area to the East of today's inactive metallurgical plants (Villalobos et al. 2010), which carried out a pyro-metallurgical process by raising the temperatures from 1000 to $1300{ }^{\circ} \mathrm{C}$ of metallic sulfide concentrates of $\mathrm{As}, \mathrm{Cu}$ and $\mathrm{Pb}$, under controlled oxidizing conditions to obtain metals of commercial value. More than a century of industrial activities in this metallurgical site resulted in the generation of waste, which dispersed to the surroundings, causing soil contamination with PTEs (Villalobos et al. 2010), and representing a potential risk to human health. The main residues generated in the plants were vitreous slag and atmospheric dusts. There are two deposits of slag South of the old facilities of the copper plant, which form mounds of compact material, one corresponds to slag of the copper plant, and the other a vitrified waste that was obtained in the furnaces of the old lead plant that operated until 1952.

The mining district of Taxco is located in SouthCentral Mexico, in the city of Taxco de Alarcón, in the state of Guerrero. The study area has a mining tradition that dates back to the Colonial era (XV century), from which waste materials have been accumulating in mine tailings impoundments. The 
tailings were placed for a long time on the banks of rivers and in areas that over the years have been surrounded by human settlements (Armienta et al. 2003). The mineralization for mining purposes appears mainly in hydrothermal veins, spare minerals and stockworks housed in limestone, slate and shale.

\section{Chemical and mineralogical analysis}

All samples were analyzed to determine total contents of $\mathrm{Tl}, \mathrm{As}, \mathrm{Pb}, \mathrm{Cu}, \mathrm{Zn}$ and $\mathrm{Cd}$ and other major elements ( $\mathrm{Fe}, \mathrm{Mn}, \mathrm{Ca}$ ) through digestions of the finely ground and 60 mesh-sieved samples (particle size less than $250 \mu \mathrm{m}$ ) with a mixture of $\mathrm{HNO}_{3}: \mathrm{HCl}: \mathrm{HF}$ (3: 1: 1), using an ultrawave ECR microwave oven operating at $260{ }^{\circ} \mathrm{C}$ for $40 \mathrm{~min}$. After digestion the total content of the metals studied were analyzed by inductively coupled plasma atomic emission spectrometry (ICP-AES) using a Perkin Elmer Optima 8300 unit. When element contents were below the detection limit of this technique analyses were carried out by inductively coupled plasma mass spectrometry (ICP-MS) using an iCAP Thermo Scientific instrument. The precision and accuracy of the digestion procedure and the analytical methods were checked using standard reference materials (CRM 2709a and Sandy Soil C). Also, these standards were used to calibrate for total $\mathrm{Tl}, \mathrm{As}, \mathrm{Pb}, \mathrm{Cu}, \mathrm{Zn}$ and $\mathrm{Cd}$ contents obtaining recovery percentages of up to $105 \%$

The mineralogy of all samples was determined via X-ray diffraction (XRD) using an Empyrean diffractometer equipped with a fine focus $\mathrm{Cu}$ tube, nickel filter, and PixCel 3D detector operating at 40 $\mathrm{mA}$ and $45 \mathrm{kV}$ at the Instituto de Geología, UNAM. For this, samples were ground with an agate pestle and mortar to $<75 \mu \mathrm{m}$ and mounted in back-side aluminum holders. The analyses were carried out on randomly oriented samples by the step scan method using the measurement range $(2 \theta)$ of 5 to $70^{\circ}$ with an integration time of $40 \mathrm{~s}$ and step size of $0.003^{\circ}$. Phase identification was made with PDF-2 and ICSD databases and semi-quantification was made using version 4.5 of HighScore Plus software and RIR (Reference Intensity Ratio) method.

The determination of the physical and chemical properties was carried out in duplicate on the $<100 \mu \mathrm{m}$ size fraction: soil $\mathrm{pH}$ and electrical conductivity (EC) were measured in 1:5 (weight/volume) and following the procedure described in the method (ISO 10390 2005).

\section{Determination of the bioaccessible (BA) fraction}

Two methods (described in detail below) were used to determine this fraction: the SBRC test (Drexler and Brattin 2007) was compared with the simple extraction proposed here using $\mathrm{HCl}$ at $\mathrm{pH} 1.5$. For these procedures sample particle sizes of less than $250 \mu \mathrm{m}$ were separated (sieved) because it is the representative size range that adheres to the hands of humans (Ruby et al. 1996).

\section{Solubility and bioavailability research consortium (SBRC)}

The SBRC test simulates the stomach digestion in terms of digestive juice composition, temperature, $\mathrm{pH}$ and transit time. To achieve this, weights of $0.500 \mathrm{~g}$ of soil or tailings, with particle size $<250$ $\mu \mathrm{m}$, were transferred to high density polyethylene containers and $50 \mathrm{~mL}$ of a $0.4 \mathrm{M}$ glycine solution was measured and transferred to each. The $\mathrm{pH}$ was adjusted to $1.5 \pm 0.1$ with concentrated $\mathrm{HCl}[37 \%$ Sigma Aldrich (Poznan, PL]. To reach this $\mathrm{pH}$ in the presence of glycine the final concentrations of $\mathrm{HCl}$ added to the different samples varied between 0.3 and $0.4 \mathrm{M}$. Subsequently, the bottles were placed in an orbital shaker to perform the extractions of PTEs with temperature control of $37 \pm 2{ }^{\circ} \mathrm{C}$, with stirring (orbital) speed of $28 \pm 2 \mathrm{rpm}$ for one hour ( $\pm 1 \mathrm{~min}$ ). The $\mathrm{pH}$ value was measured at $5,10,15$ and 30 minutes, readjusting if necessary (depending on the type of samples).

\section{Hydrochloric acid-extractable fraction}

A modified version of the European Standard Toy Safety Protocol EN-71 (European Committee for Standardization 1995) proposed by Rasmussen et al. (2008) was used to determine HCl-extractable PTEs contents. Various dilutions of concentrated $\mathrm{HCl}$ [37 \% from Sigma Aldrich (Poznan, PL)] were used to adjust the samples to $\mathrm{pH}=1.5$.

Weights of $0.500 \mathrm{~g}$ of soil or tailings, with particle size $<250 \mu \mathrm{m}$, were transferred to a wide-mouth polyethylene container. $50 \mathrm{~mL}$ of the appropriate dilution of $\mathrm{HCl}$ (with final concentrations between $0.03 \mathrm{M}$ and $0.1 \mathrm{M}$ ) was measured and transferred to the container yielding a sample mass to fluid ratio of 1:100 (g:mL), which is the modification of the EN-71 Toy Safety protocol and of the method by Dodd et al. (2013) (1: 2000). The samples were placed on an oscillating shaker at $300 \mathrm{rpm}$ at room temperature for one hour ( $\pm 1 \mathrm{~min})$. The $\mathrm{pH}$ of the extractant solution was evaluated at 5,10,15 and 30 minutes and readjusted so that the $\mathrm{pH}$ of the solution did not vary from the range of $1.5 \pm 0.1$.

The PTEs contents from both extractions were determined by ICP-AES, except for thallium, by ICP-MS. The reproducibility of the measurements 
was evaluated by analyzing all samples and a blank consisting of $50 \mathrm{~mL}$ of $0.4 \mathrm{M}$ glycine solution at $\mathrm{pH}$ 1.5 or $50 \mathrm{~mL}$ of $0.03 \mathrm{M} \mathrm{HCl}$ solution at $\mathrm{pH} 1.5$ in triplicate. The results were considered satisfactory when the coefficient of variation of these measurements was less than $10 \%$.

Absolute PTEs gastric BA was calculated by dividing the extracted content (termed SBRC-G and HCl-G) by the total soil PTE content (Eq. 1).

Absolute PTE bioaccessibility,

$$
\%=[\text { In vitro PTE/Total PTE }] \times 100
$$

Where: In vitro PTE $=$ PTE $(\mathrm{mg} / \mathrm{kg})$ extracted from soil following either gastric phase extraction (SBRC-G or HCl-G), and Total PTE ( $\mathrm{mg} / \mathrm{kg}$ ) present in the contaminated soil.

\section{Filtration method}

In the literature different methods of separation of the dissolved (BA) fraction are reported. Among the most common are the use of centrifugation and microfiltration (pore size $0.45 \mu \mathrm{m}$ ) (Ruby et al. 1996, Mingot et al. 2011, Laird et al. 2015, Li et al. 2015, Zong et al. 2016).

In this research work the use of membranes with different pore sizes was evaluated to separate the dissolved from the solid (colloidal) phase: pore size $0.45 \mu \mathrm{m}$, corresponding to microfiltration, and 0.05 $\mu \mathrm{m}$, corresponding to nanofiltration. It is expected that by reducing the pore size in the filtration, this will simulate better the PTEs absorption processes in the intestinal phase.

Therefore, the aqueous concentrations of PTEs were obtained after nanofiltration of the extracts by using Amicon ultrafilters (Amicon Ultra-15 10K, Millipore, MA) containing porous cellulose membranes with a pore size of $0.05 \mu \mathrm{m}$.

\section{Statistical analysis}

All determinations were made in triplicate. To evaluate the variability of the results in the quantifications of the total contents and in the extractions performed, the coefficients of variation (CV) were calculated from the averages and standard deviations for each sample. A CV of less than $10 \%$ was accepted. The Pearson correlation analysis was performed by comparing the results of the physical and chemical parameters, with the total contents of PTE in soil particles of less than $<250 \mu \mathrm{m}$ and in the gastric phase BA extracts. The correlation coefficient values were compared with those found in tables with a significance of 1 and $5 \%$, with n-2 degrees of freedom (Rollinson 1993). Significance values greater than those found in tables for $1 \%$ were considered as strongly correlated.

Comparisons between both BA methods were performed using linear regressions.

\section{RESULTS AND DISCUSSION}

\section{Soils properties and total contents of major ele- ments and PTEs}

Table I shows the characterization results of all analyzed samples: $\mathrm{pH}$, electrical conductivity (EC), total contents of major elements and PTEs analyzed.

In the soils of SLP, variable $\mathrm{pH}$ values between 4.82 and 10.1 were found. Sample SLP06 showed a high $\mathrm{pH}$ value $(=10.1)$ and $\mathrm{EC}$ value $\left(2.00 \times 10^{4} \mu \mathrm{S} / \mathrm{cm}\right)$, suggesting contamination by alkaline residues. The EC interval was also very variable, from 200 to $2.00 \times 10^{4} \mu \mathrm{S} / \mathrm{cm}$, values belonging to SLP08 and SLP06, respectively. However, the $\mathrm{pH}$ of the sample with the next highest EC value of $5.40 \times 10^{3}$, was only 6.01 (SLP09). Therefore, if the EC is better indicative of external contamination by waste, it is clear that not all residues necessarily contain alkaline components.

Taxco (TX) samples yielded an average $\mathrm{pH}$ of $6.40 \pm 0.66(n=22)$ considering the soils and tailings together. The highest $\mathrm{pH}$ values were found in TXP3a and TXP4a with a value of 7.00 for both. The lowest value was registered for TXP3c with a $\mathrm{pH}$ of 4.40 , suggesting some acid mine drainage (AMD) formation.

All samples of tailings and soils from "La Concha" (brown $=$ oxidized) showed near-neutral $\mathrm{pH}$ values (6.10-6.90), which suggests the presence of acid-neutralizing minerals (Romero and Gutiérrez 2010). They all showed low EC, in a range of $83.0-162 \mu \mathrm{S} / \mathrm{cm}$, which indicates that the sulfates of soluble metals formed during oxidation of sulfides in tailings have been leached out of the system.

In general, when descending in the profiles of "El Fraile" mine tailings, the $\mathrm{pH}$ begins at neutral values and becomes rapidly more acidic and the EC increases, indicating that AMD is being formed but is transported downwards. Somehow, neutralization is happening only at the surface and not in deeper horizons, but it is not clear what the reason or mechanism is.

The soils adjacent to the "El Fraile" tailings impoundment had $\mathrm{pH}$ values close to neutral $(\mathrm{pH}=$ 6.60 and 6.20) and the EC was lower than the tailings samples (46.0 and $62.0 \mu \mathrm{s} / \mathrm{cm}$ ).

In the "Foster" tailings impoundment, the average $\mathrm{pH}$ of the samples was very close to neutral, $\sim 6.40$. 
TABLE I. PHYSICAL AND CHEMICAL PROPERTIES OF SOILS AND TOTAL CONCENTRATION OF MAJOR ELEMENTS AND OF POTENTIAL TOXIC ELEMENTS (PTES), SEPARATED BY LOCATION

\begin{tabular}{|c|c|c|c|c|c|c|c|c|c|c|c|}
\hline \multirow{3}{*}{ Samples } & \multicolumn{11}{|c|}{ Total Concentration } \\
\hline & \multicolumn{11}{|c|}{$\mathrm{mg} / \mathrm{kg}$} \\
\hline & $\mathrm{pH}$ & $\begin{array}{c}\text { Electrical } \\
\text { Conductivity } \\
(\mu \mathrm{S} / \mathrm{cm})\end{array}$ & $\begin{array}{c}\mathrm{Fe} \\
(\%)\end{array}$ & $\begin{array}{l}\mathrm{Ca} \\
(\%)\end{array}$ & $\begin{array}{l}\mathrm{Mn} \\
(\%)\end{array}$ & $\mathrm{Tl}$ & As & $\mathrm{Pb}$ & $\mathrm{Cu}$ & $\mathrm{Zn}$ & $\mathrm{Cd}$ \\
\hline \multicolumn{12}{|c|}{ Soils from the metallurgical site. From SLP } \\
\hline SLP01 & 6.81 & 710 & 1.98 & 0.511 & 0.054 & 4.12 & 869 & $1.06 \times 10^{3}$ & 926 & $6.74 \times 10^{3}$ & 167 \\
\hline SLP02 & 4.82 & $1.00 \times 10^{3}$ & 3.91 & 0.512 & 0.052 & 4.22 & $1.06 \times 10^{4}$ & $1.11 \times 10^{4}$ & $1.98 \times 10^{3}$ & $3.18 \times 10^{3}$ & 264 \\
\hline SLP03 & 5.73 & 310 & 6.90 & 0.690 & 0.042 & 1.56 & $7.34 \times 10^{3}$ & $1.17 \times 10^{4}$ & $2.96 \times 10^{4}$ & $9.18 \times 10^{3}$ & 406 \\
\hline SLP04 & 5.31 & $1.7 \times 10^{3}$ & 3.54 & 1.11 & 0.134 & 3.08 & $3.69 \times 10^{4}$ & $7.98 \times 10^{3}$ & $3.43 \times 10^{3}$ & $5.68 \times 10^{3}$ & 594 \\
\hline SLP05 & 6.60 & 290 & 5.37 & 1.38 & 0.060 & 2.83 & $1.24 \times 10^{4}$ & $1.08 \times 10^{4}$ & $1.97 \times 10^{4}$ & $9.57 \times 10^{3}$ & $1.31 \times 10^{3}$ \\
\hline SLP06 & 10.1 & $2.00 \times 10^{4}$ & 10.1 & 2.83 & 0.520 & 11.9 & $3.29 \times 10^{4}$ & $1.88 \times 10^{4}$ & $9.69 \times 10^{3}$ & $4.60 \times 10^{4}$ & $2.26 \times 10^{3}$ \\
\hline SLP07 & 6.22 & $2.40 \times 10^{3}$ & 12.0 & 1.40 & 0.180 & 3.25 & $1.62 \times 10^{3}$ & $5.14 \times 10^{3}$ & $2.61 \times 10^{4}$ & $1.74 \times 10^{3}$ & $3.26 \times 10^{3}$ \\
\hline SLP08 & 6.81 & 200 & 2.37 & 0.612 & 0.130 & 7.11 & $1.64 \times 10^{3}$ & $6.04 \times 10^{3}$ & $7.95 \times 10^{3}$ & $1.85 \times 10^{4}$ & 98.0 \\
\hline SLP09 & 6.01 & $5.40 \times 10^{3}$ & 8.00 & 0.791 & 0.026 & 46.7 & $6.00 \times 10^{5}$ & $2.12 \times 10^{5}$ & $4.87 \times 10^{4}$ & $2.66 \times 10^{5}$ & $3.93 \times 10^{4}$ \\
\hline
\end{tabular}

Soils from mine waste sites (TX)

\begin{tabular}{|c|c|c|c|c|c|c|c|c|c|c|c|}
\hline \multicolumn{12}{|c|}{ "La Concha" tailings impoundment (brown- oxidized tailings) } \\
\hline TXP1a & 6.20 & 119 & 19.6 & 8.32 & 1.41 & 1.46 & $2.29 \times 10^{3}$ & $2.00 \times 10^{4}$ & 864 & $3.94 \times 10^{4}$ & 274 \\
\hline TXP1b & 6.30 & 83.1 & 21.7 & 8.41 & 1.34 & 1.68 & $2.38 \times 10^{3}$ & $2.22 \times 10^{4}$ & $1.12 \times 10^{3}$ & $4.82 \times 10^{4}$ & 435 \\
\hline TXP1c & 6.70 & 114 & 35.7 & 7.00 & 2.32 & 1.87 & $4.10 \times 10^{3}$ & $4.05 \times 10^{4}$ & $1.96 \times 10^{3}$ & $5.80 \times 10^{4}$ & 544 \\
\hline TXP2a & 6.90 & 61.3 & 21.0 & 10.0 & 1.28 & 1.19 & $2.03 \times 10^{3}$ & $2.04 \times 10^{4}$ & $1.23 \times 10^{3}$ & $8.28 \times 10^{4}$ & 643 \\
\hline TXP2b & 6.70 & 88.3 & 23.3 & 11.1 & 1.38 & 1.38 & $2.65 \times 10^{3}$ & $2.85 \times 10^{4}$ & $1.56 \times 10^{3}$ & $7.54 \times 10^{4}$ & 793 \\
\hline TXP2c & 6.80 & 162 & 18.4 & 7.30 & 1.15 & 1.41 & $2.28 \times 10^{3}$ & $2.84 \times 10^{4}$ & $1.33 \times 10^{3}$ & $7.21 \times 10^{4}$ & 557 \\
\hline \multicolumn{12}{|c|}{ "El Fraile” tailings impoundment (varied tailings) } \\
\hline TXP3a & 7.00 & 156 & 2.60 & 9.22 & 0.021 & 0.400 & 122 & 147 & 59.0 & 212 & $<$ D.L \\
\hline TXP3b & 6.50 & 965 & 8.40 & 2.38 & 0.022 & 1.34 & $2.03 \times 10^{3}$ & $3.45 \times 10^{3}$ & 160 & 885 & $<$ D.L \\
\hline TXP3c & 4.40 & $1.90 \times 10^{3}$ & 4.96 & 2.69 & 0.075 & 0.750 & 919 & $1.93 \times 10^{3}$ & 989 & $4.62 \times 10^{3}$ & 41 \\
\hline TXP4a & 7.00 & 145 & 3.00 & 7.13 & 0.050 & 0.490 & 193 & 388 & 101 & 625 & $<$ D.L \\
\hline TXP4b & 4.70 & 317 & 7.60 & 0.490 & 0.042 & 0.840 & $1.22 \times 10^{3}$ & $2.08 \times 10^{3}$ & 100 & 742 & $<$ D.L \\
\hline TXP4c & 5.40 & $1.13 \times 10^{3}$ & 8.80 & 1.92 & 0.640 & 0.690 & $1.50 \times 10^{3}$ & $1.90 \times 10^{3}$ & 317 & $1.58 \times 10^{4}$ & 131 \\
\hline \multicolumn{12}{|c|}{ "Foster" tailings impoundment (gray-fresh reduced tailings) } \\
\hline TXP5a & 6.30 & 834 & 15.0 & 10.3 & 0.860 & 1.10 & 843 & 588 & 112 & $4.71 \times 10^{3}$ & 45.0 \\
\hline TXP5b & 6.30 & 988 & 15.6 & 10.2 & 0.890 & 1.00 & 925 & 524 & 136 & $4.21 \times 10^{3}$ & 57.0 \\
\hline TXP5c & 6.40 & 911 & 20.6 & 8.12 & 1.00 & 1.29 & 795 & 350 & 168 & $7.66 \times 10^{3}$ & 101 \\
\hline TXP6a & 6.50 & 600 & 20.0 & 9.26 & 0.930 & 1.20 & 842 & 313 & 87 & $2.80 \times 10^{3}$ & 36.0 \\
\hline TXP6b & 6.50 & 627 & 16.3 & 10.4 & 0.942 & 1.20 & 660 & 314 & 118 & $2.56 \times 10^{3}$ & 38.0 \\
\hline TXP6c & 6.60 & 523 & 18.3 & 10.8 & 1.04 & 1.30 & 956 & 385 & 124 & $3.09 \times 10^{3}$ & 43.0 \\
\hline \multicolumn{12}{|c|}{ Soil samples near "La Concha” impoundment } \\
\hline TXSC1 & 6.10 & 138 & 14.3 & 6.14 & 0.63 & 0.740 & $2.18 \times 10^{3}$ & $1.01 \times 10^{4}$ & 537 & $3.84 \times 104$ & 333 \\
\hline TXSC2 & 6.40 & 78.4 & 3.51 & 4.09 & 0.08 & 0.810 & 187 & $1.29 \times 10^{3}$ & 111 & $3.84 \times 103$ & 30.0 \\
\hline \multicolumn{12}{|c|}{ Soil samples near "El Fraile" impoundment } \\
\hline TXSF1 & 6.60 & 46.4 & 15.4 & 0.602 & 0.300 & 0.500 & $1.88 \times 10^{3}$ & $4.21 \times 10^{3}$ & 344 & $1.47 \times 10^{3}$ & 20.0 \\
\hline TXSF2 & 6.62 & 62.6 & 7.85 & 1.77 & 0.072 & 0.480 & 899 & $5.56 \times 10^{3}$ & 92.0 & $1.35 \times 10^{3}$ & $<$ D.L \\
\hline
\end{tabular}

$<$ D.L Below detection limit 
The electrical conductivity of the samples was found in a range between 600 and $988 \mu \mathrm{S} / \mathrm{cm}$.

The total Fe contents in the two locations are quite high, but considerably higher for TX than for SLP $(15.5 \pm 8.15 \%$ and $5.37 \pm 3.50 \%$ respectively). In the case of TX, the values in tailings are much higher (more than double on average) than in soils, which is a reflection of the high initial content of pyrite $\left(\mathrm{FeS}_{2}\right)$ in waste tailings from mines. In TX soils, the values are also greater than those of SLP, probably from contamination from tailings.

The contents of total $\mathrm{Ca}$ in TX $(7.71 \pm 3.59 \%)$ are seven times higher than in SLP $(0.79 \pm 0.74 \%)$ suggesting higher calcite and/or gypsum contents in TX. Total Mn in TX $(0.875 \pm 0.616 \%)$ was also sixteen times higher than in SLP $(0.06 \pm 0.15 \%)$.

The amorphous minerals of $\mathrm{Mn}$ (III) and (IV) provide active sites on their surfaces and internal structures on which PTEs cations can be sorbed (Villalobos et al. 2005, Peacock and Moon 2012, Villalobos et al. 2014, Voegelin et al. 2015, Atkins et al. 2016, Wick et al. 2018). A high correlation was found between the total contents of $\mathrm{Tl}$ and $\mathrm{Mn}(\mathrm{r}=$ $0.89, p<0.01$, not considering the sample SLP09), suggesting a strong association between these metals (Cruz-Hernández et al. 2018). The rest of PTEs did not show correlations with $\mathrm{Mn}$.

A very important correlation between total $\mathrm{Mn}$ and Fe was found in TX soils $(\mathrm{r}=0.94, \mathrm{p}<0.01)$, which reveals their common origin.

The Mexican standard (NOM-147-SEMARNAT/ SSA1-2004) (SEMARNAT 2007) defines as limits of total $\mathrm{Tl}$ for non-contaminated soils a value below $5.20 \mathrm{mg} / \mathrm{kg}$ for residential and agricultural areas, and a value below $67.0 \mathrm{mg} / \mathrm{kg}$ for industrial use; for As $22.0 \mathrm{mg} / \mathrm{kg}$ and $260 \mathrm{mg} / \mathrm{kg}$, respectively; for $\mathrm{Pb}$ $400 \mathrm{mg} / \mathrm{kg}$ and $800 \mathrm{mg} / \mathrm{kg}$, respectively; and for $\mathrm{Cd}$ $37.0 \mathrm{mg} / \mathrm{kg}$ and $450 \mathrm{mg} / \mathrm{kg}$, respectively.

The samples collected have higher concentrations of the regulated elements $\mathrm{As}, \mathrm{Cd}$ and $\mathrm{Pb}$. In the case of $\mathrm{Tl}$, the reported values are below the norm. There are other standards such as Decree 18/2015 of the Junta de Andalucía in Spain that set lower limits: lower than $0.23 \mathrm{mg} / \mathrm{kg}$ for residential and agricultural areas, and a value lower than $2.30 \mathrm{mg} / \mathrm{kg}$ for industrial use in other areas.

\section{Mineralogical characterization}

The results derived from the XRD analysis are shown in Table SII.

In SLP the mineralogical composition is highly variable. There are major components of most of the primary mineral such as quartz, feldspar and plagio- clase and minor secondary iron oxide minerals such as hematite and goethite in samples SLP01, SLP02 and SLP08. In samples SLP03, SLP04 and SLP07 the presence of mica and secondary minerals (neoformed or not) such as gypsum and jarosite as minor components is noteworthy (Cruz-Hernández et al. 2018).

In TX the mineralogical composition through all profiles is quite similar and consists of primary minerals of iron such as pyrite. In addition, there is quartz and pyroxene of diopside type. As secondary minerals it contains gypsum and calcite. On the one hand the presence of gypsum is a signal of a certain oxidation degree, but the presence of remnant calcite ensures neutralization of the protons formed during sulfide oxidation, which in turn slows down the oxidative process. The semi-quantitative analysis also shows high mineral contents of the micas, and potassic feldspars groups as well as crystalline iron oxides such as goethite. On the other hand, samples without pyrite contained jarosite. Mica was identified in all samples. In soils of TX, quartz was found as the predominant mineral. In general, jarosite, calcite, feldspar and mica are the most abundant mineral phases present.

\section{Determination of the BA fraction Comparison of filtration methods}

To compare the two filtration methods, four soil and tailing samples were selected to perform the single extraction, filtering through each of the two membranes. The results obtained are shown in figure 2.

Although for some elements no significant differences were found between the two filtering methods $(\mathrm{p}<0.05)$, in many others the differences were highly significant (Fig. 2). Two very relevant observations can be made for all cases of significant differences: (1) The contents measured in the filtrates through $0.45 \mu \mathrm{m}$ pore membranes were always higher than those through $0.05 \mu \mathrm{m}$ pores. This suggests that colloids smaller than $450 \mathrm{~nm}$ that can pass through the first membrane contribute in the measurement by ICP-AES of the total "dissolved" element in a significant way, and (2) The standard deviation of the data with the membrane of $0.45 \mu \mathrm{m}$ was always considerably higher than that with the membrane of $0.05 \mu \mathrm{m}$, which suggests that the presence of these suspended colloids causes greater variability in the measurements by this technique, as compared to the almost purely dissolved phase from the filtrate through the $0.05 \mu \mathrm{m}$ pore.

These results justified the widespread use of the $0.05 \mu \mathrm{m}$ pore membranes in all subsequent BA extractions. 

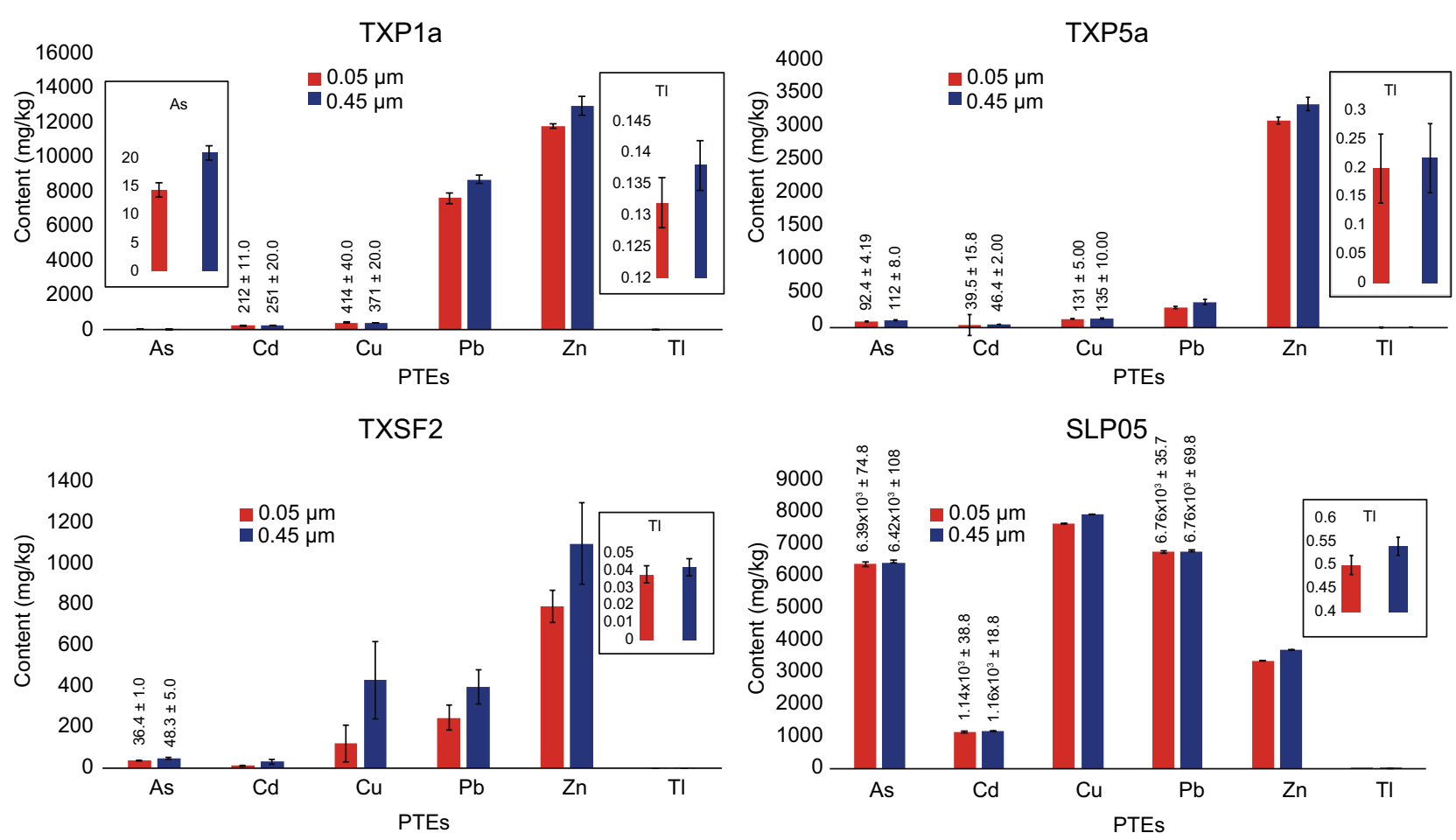

Fig. 2. Potential toxic elements (PTEs) contents after a simple extraction with hydrochloric acid (HCl) at $\mathrm{pH} 1.5$ for one hour with filtration through two membranes of different pore size: $0.05 \mu \mathrm{m}$ and $0.45 \mu \mathrm{m}$. Error bars indicate standard error

In this study, the use of dialysis membranes with a considerably smaller pore size and closer to that expected in intestinal tissues was also evaluated. However, the use of this type of filtration requires a longer time for complete ion diffusion across the membrane (3.5 hours), which clearly surpasses the one hour established of the extraction method. In the digestion process the dissolution status of the minerals present is far from an equilibrium state at the imposed $\mathrm{pH}$ of 1.5 and one hour, in which it may be, in fact, in a state of fast dissolution kinetics. For this reason, maintaining the same exact extraction time is crucial for obtaining reproducible results. Therefore, the dialysis membrane filtration method could not be applied and the use of $0.05 \mu \mathrm{m}$ membranes was decided to be sufficient to have the best possible separation of the dissolved phase.

\section{Gastric BA of PTEs \\ General aspects}

Table II shows the gastric BA contents of PTEs by the two methods studied.

SLP samples showed the highest contents of extractable PTEs. This is because the metallurgical treatment usually consists of aggressive oxidation processes, which makes PTEs concentrated in the residues more mobile and soluble (Cruz-Hernández et al. 2018).

In the TX mining area the tailings contain PTEs in various stages of oxidation, from more reduced to more oxidized forms. However, a high degree of oxidation is expected in the soils of this zone, but a lower percentage of BA is observed for As (Table II) when comparing the results of both zones (SLP and TX).

BA contents of As were lower in the samples of oxidized tailings (brown, TXP1 and TXP2) than in the samples of reduced tailings (gray, TXP5 and TXP6) (Table II). This is due to the presence of secondary minerals, such as jarosites that can retain As in their structures, and which were detected by XRD (Table SII). This is the reason why the $\% \mathrm{BA}$ of As in the gastric phase is low compared to the other PTEs (Table II). Therefore, it would be worth investigating this speciation with more mineralogical detail in future studies. In contrast, in SLP soils the BA values reach up to over $60 \%$, which is indicative of an As mineralization very different from that of the tailings and soil samples from TX. Most samples of SLP contain arsenolite $\left(\mathrm{As}_{2} \mathrm{O}_{3}\right)$, a very soluble mineral of As(III) (Koch et al. 2011). 


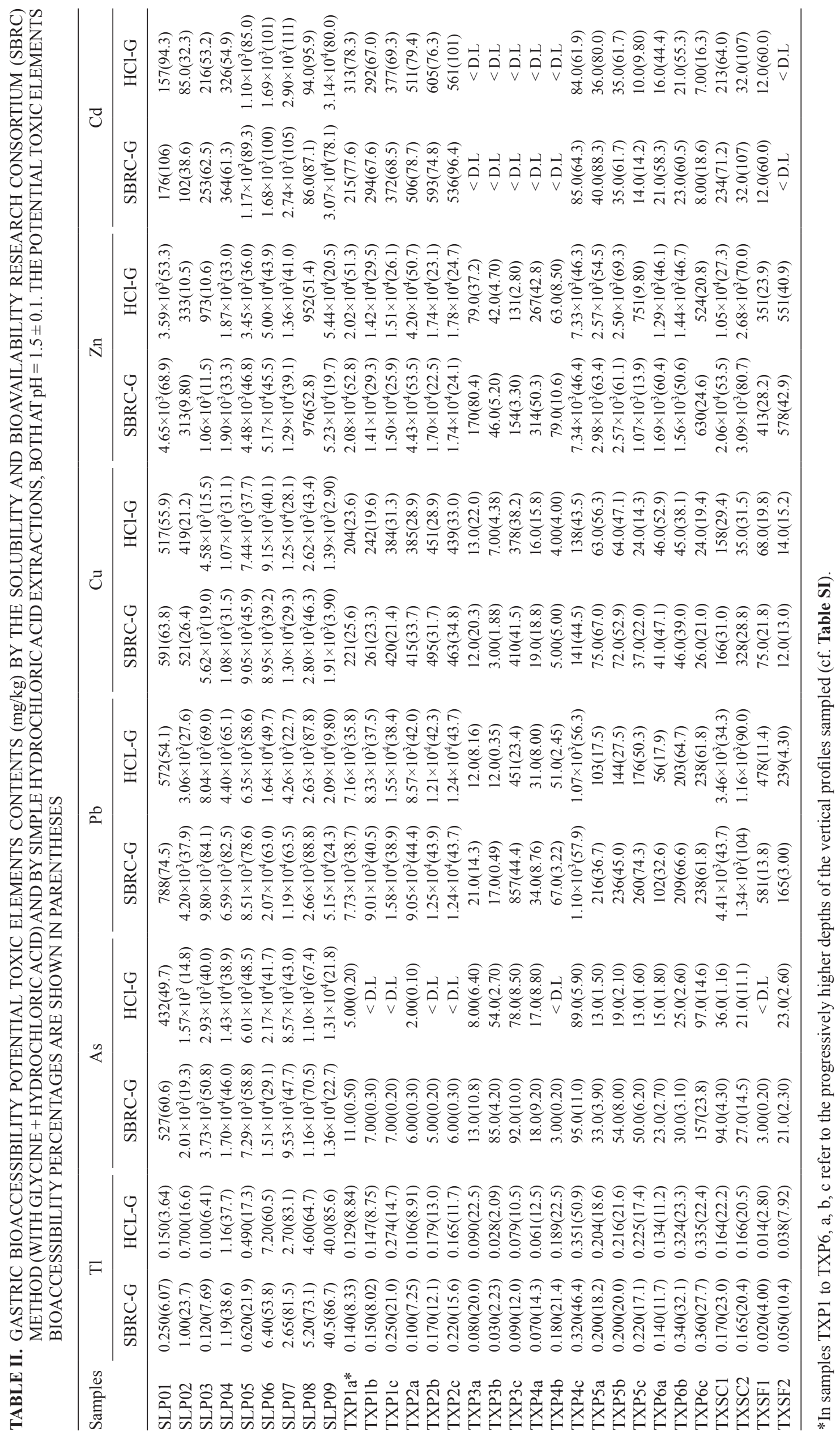


Unlike As, the BA contents of $\mathrm{Cd}$ are higher in oxidized tailings and soils (67.6 to $96.4 \%$ ) than in reduced tailings (14.2 to $88.3 \%$ ). The high BA values reflect that $\mathrm{Cd}$ is not strongly bound to minerals or that it forms highly soluble minerals. The acidic conditions of the gastric phase produce the release of As, $\mathrm{Cd}, \mathrm{Cu}, \mathrm{Zn}, \mathrm{Tl}$ and $\mathrm{Pb}$ (Juhasz et al. 2010) due to the dissolution of the mineral phases present in addition to the formation of stable complexes. The chlorides from the $\mathrm{HCl}$ extractant play an important role in the formation of cadmium chloride complexes, which make it more soluble and mobile (EEA 2014). In reduced tailings where sulfides prevail, Cd mobility from $\mathrm{CdS}$ formation is expected to be much lower than in their oxidized (sulfated) counterparts.

Copper in soils usually is strongly but reversibly bound to organic matter (Violante et al. 2010). The samples analyzed have total $\mathrm{Cu}$ contents that range between $59.0 \mathrm{ppm}$ and $4.87 \times 10^{4} \mathrm{ppm}$ (Table I), with the soils of the metallurgical zone having the highest contents, followed by oxidized tailings $>$ soils in the mining area $>$ reduced tailings. $\mathrm{Cu}$ forms very stable complexes in the presence of organics, which promote high BA values. The calculated bioaccessible contents in the samples ranged between $5 \%$ and 75 $\%$, depending on the characteristics of the sample. For example, SLP09 shows that although it has a high total copper content, $4.87 \times 10^{4} \mathrm{mg} / \mathrm{kg}$, its high BA value of $1.91 \times 10^{3} \mathrm{mg} / \mathrm{kg}$ represents only $3.90 \%$.

Gastric BA values of $\mathrm{Pb}$ in TX are greater in reduced tailings (gray - TXP5, TXP6) than in oxidized tailings (brown - TXP1, TXP2), in contrast to Cd, although the total content of $\mathrm{Pb}$ in gray tailings is lower than in oxidized tailings. It is note worthy that gray tailings contain much higher content of anglesite $\left(\mathrm{PbSO}_{4}\right)$, where $\mathrm{Pb}$ is more $\mathrm{BA}$ than in other $\mathrm{Pb}$ minerals, including $\mathrm{Pb}$ arsenates like mimetite, which are found in similar proportions in both types of tailings (Palumbo-Roe et al. 2013) (Table SII).

In summary, the $\mathrm{BA}$ contents of $\mathrm{Pb}$ in the soil samples vary greatly from one zone to another, indicating a wide range of $\mathrm{Pb}$ minerals or $\mathrm{Pb}$ associations with variable extractability behavior at low $\mathrm{pH}$. $\mathrm{Pb}$ carbonates and sulfates may be very soluble, while arsenates may not (Vaca-Escobar and Villalobos 2005).

Smithsonite $\left(\mathrm{ZnCO}_{3}\right)$ is the main zinc mineral species in the tailings (Table SII), which is very soluble in the extraction conditions and contributes highly to $\mathrm{Zn}$ BA. Oxidized tailings have the highest total zinc content. The bioaccessible percentage varied from $5.00 \%$ to $70.0 \%$, indicating again a wide range of BA in the different $\mathrm{Zn}$ minerals, however a trend is observed in that the surface samples have the highest BA con- tents. According to the observed results, in the TXP3 and TXP4 (varied tailings) vertical profiles, the BA contents in the $\mathrm{b}$ horizon are lower than in the $\mathrm{a}$ and $\mathrm{c}$ horizons. Whereas a higher BA content is found in the $\mathrm{c}$ horizon of the reduced tailing $(\mathrm{a}, \mathrm{b}$, and $\mathrm{c}$ indicating progressively deeper horizons - cf. Table SII).

Thallium (Tl), although found in much lower content than all the PTEs analyzed, is the most toxic inorganic pollutant regulated in soil and water (Peter and Viraraghavan 2005, Rodriguez-Mercado and Altamirano-Lozano 2013). The BA percentages of T1 vary between 4.00 and $86.7 \%$, the SLP zone showing the highest BA contents of Tl, evidently highly correlated to the Mn BA content (Fig. SI). Previous studies on this metallurgical zone (Cruz-Hernández et al. 2018) showed evidences of $\mathrm{Tl}$ bonding with poorly-crystalline manganese oxides. The considerably high BA Mn contents is surprising, considering $\mathrm{Mn}(\mathrm{III} / \mathrm{IV}$ ) oxides cannot dissolve, except through a reductive dissolution mechanism. This suggests that $\mathrm{HCl}$ may be acting as a mild reducing agent (Table SIII), because using $\mathrm{HNO}_{3}$ instead yields much lower extracted Mn (Cruz-Hernández et al. 2018).

In the case of TX samples, the percentages of Tl BA may be attributed to carbonate binding (Table SII), where $\mathrm{Tl}(\mathrm{I})$ can be coprecipitated in the mineral calcite (Cruz-Hernández et al. 2018). Also, weakly sorbed $\mathrm{Tl}$ species may be present.

It is difficult to compare these $\mathrm{Tl}$ data with other studies, due to the different extraction protocols used, the different types of soils and the different particle sizes used, in addition to the non-existence in the literature of $\mathrm{Tl} \mathrm{BA}$ data in contaminated soils from mining waste.

Finally, in general, the contents extracted with $\mathrm{HCl}$ alone $(\mathrm{pH} \mathrm{1.5)}$ are very close to those obtained using the glycine (SBRC) method. Although for some samples and elements the contents obtained with the glycine method are slightly higher, as will be described below.

\section{Correlations between extraction methods}

To evaluate whether the simple extraction method with $\mathrm{HCl}$ is an adequate method to predict gastric$\mathrm{BA}$ as dictated by the SBRC test, the degree of linear correlation between both extraction results was determined for each element investigated, and the values of the slopes obtained were compared to a desirable value of 1 . These correlations are presented in figure 3 , but separately for SLP (Fig. 3A) and TX (Fig. 3B) since the PTEs contents of SLP are much higher and overwhelm those of TX when plotted together. 

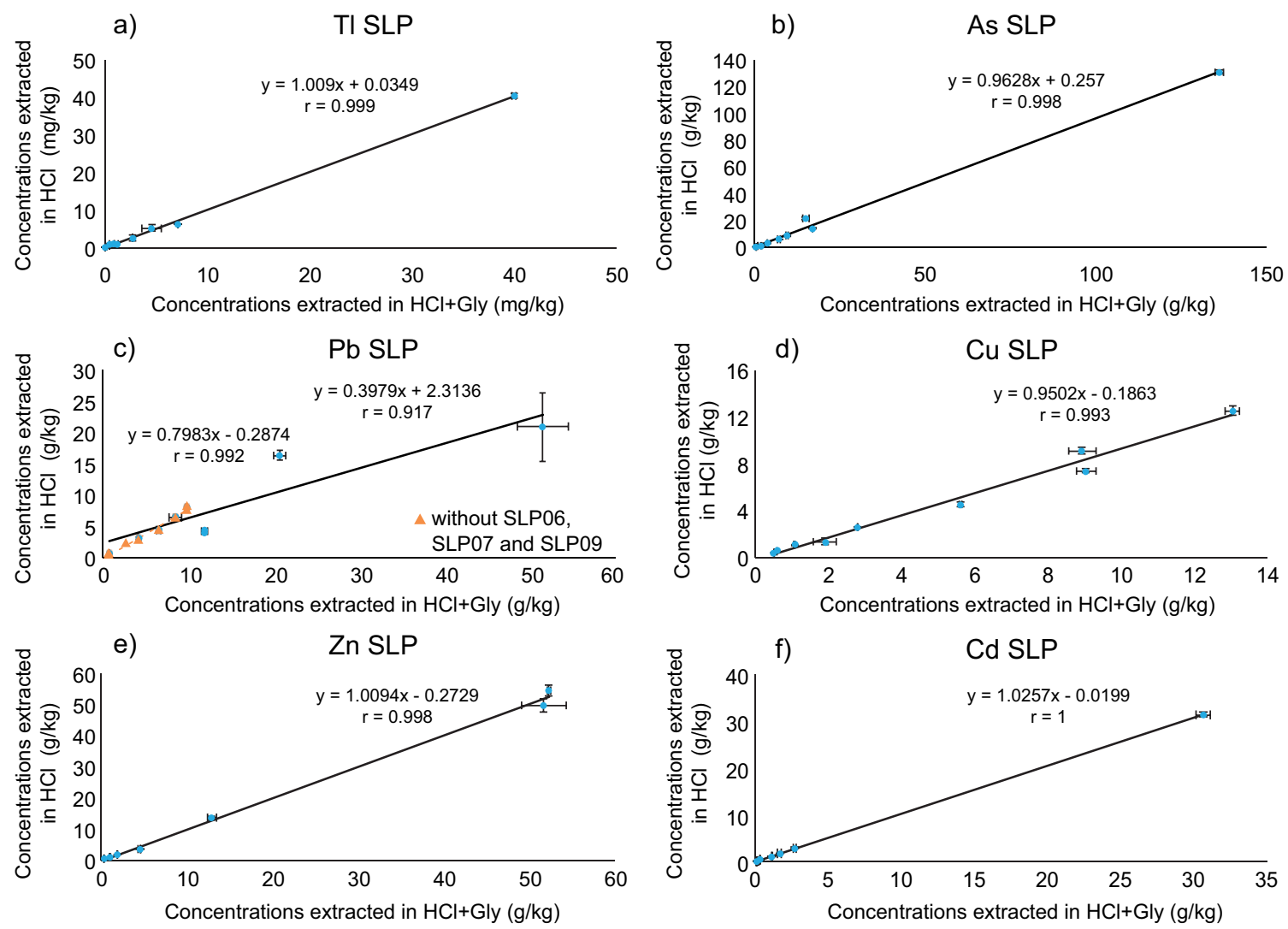

Fig. 3A. Correlations obtained between extracted potential toxic elements (PTEs) for the two bioaccessibility (BA) methods evaluated in San Luis Potosí (SLP) samples, at $\mathrm{pH}$ 1.5: with hydrochloric acid (HCl) alone and with hydrochloric acid + Glycine $(\mathrm{HCl}+\mathrm{Gly})$ (solubility and bioavailability research consortium, SBRC test). Errors bars indicate standard error

It is clear that all elements in both settings show perfect correlations, with $\mathrm{r}$ values above 0.99 , and some even of 1 , and with slopes from 0.92 to 1.03 , which indicates that the SBRC test using additionally glycine can be replaced with full confidence by the simpler $\mathrm{HCl}$ method. With two notable exceptions: $\mathrm{Pb}$ in SLP samples (Fig. 3Ac), and As in TX mine tailings (Fig. 3Bh).

In contrast, $\mathrm{Pb}$ in TX samples yielded an equally perfect correlation as the other PTEs with an $\mathrm{r}=1.0$, p $<0.01$ (Fig. 3Bi), as did As in SLP (Fig. 3Ab). In the $\mathrm{Pb}$ case in SLP, samples were plotted separately, excluding SLP 06, 07 and 09 (shown in triangles Fig. $3 \mathrm{Ac}$ ), because of their higher EC values and total $\mathrm{Fe}$ contents as compared to the other samples (Table I). The remaining samples showed a perfect correlation between BA extraction methods $(\mathrm{r}=0.99, \mathrm{p}<0.01)$, although their slope was lower than $1(0.8)$, which denotes a higher extractability of the combination of glycine and $\mathrm{HCl}$ (SBCR test) as compared to the $\mathrm{HCl}$ alone, and suggests $\mathrm{Pb}$ minerals have a higher solubility when glycine is present. Nevertheless, in those cases, when the correlation is so high, it is still unnecessary to include glycine in the BA test, and the correlation found may be used to convert to actual (SBCR) BA values.

In the SLP samples that did not yield correlation for $\mathrm{Pb}$, we observed that they all contained anglesite $\left(\mathrm{PbSO}_{4}\right)$, especially SLP09 and 06 (Table SII), in higher concentrations than all others, including those of TX. Therefore, we tested if indeed anglesite yielded a different extraction capacity in the presence of glycine by applying the same procedure as in the real samples, but using only pure anglesite. Indeed, glycine $+\mathrm{HCl}$ dissolved a considerably higher concentration of anglesite $\left(6.20 \times 10^{4} \mathrm{mg} / \mathrm{kg}\right)$ than $\mathrm{HCl}$ alone $\left(1.40 \times 10^{4} \mathrm{mg} / \mathrm{kg}\right)$ under the same extraction conditions.

In the case of As in TX mine tailings, the explanation for the lack of correlation between the two BA extraction methods was not that clear. The results 

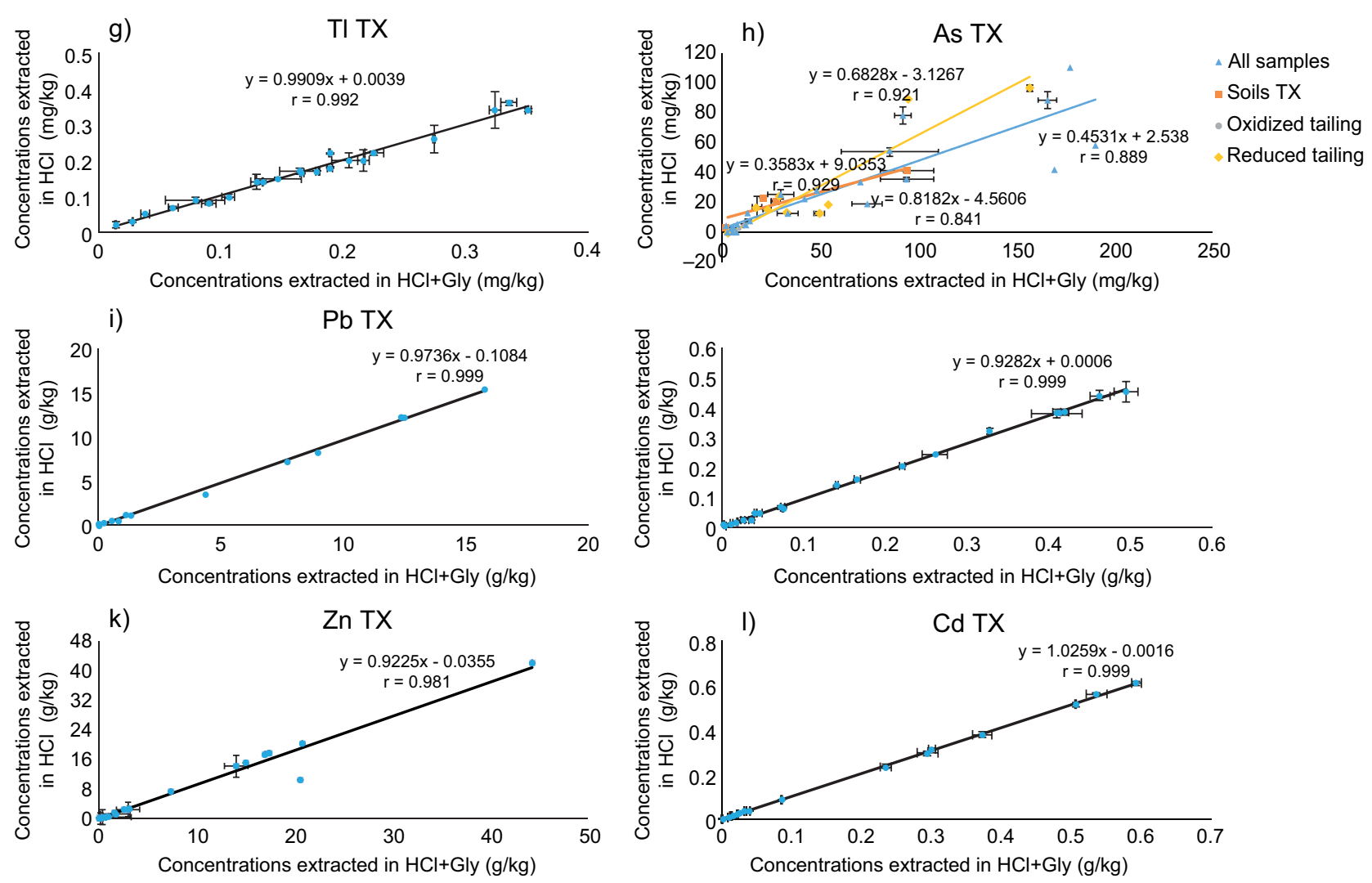

Fig. 3B. Correlations obtained between extracted potential toxic elements (PTEs) for the two bioaccessibility (BA) methods evaluated in Taxco (TX) samples, at pH 1.5: with hydrochloric acid alone and with hydrochloric acid + Glycine ( $\mathrm{HCl}+\mathrm{Gly})$ (solubility and bioavailability research consortium, SBRC test). Errors bars indicate standard error

have been separated according to the characteristics of the samples: in oxidized tailings, reduced tailings, and soils, in order to evaluate whether the correlations improved. Only slight improvements were obtained for the soil samples $(r=0.93, \mathrm{p}<0.01)$, although their slope remained considerably lower than 1 , while the tailings still showed high dispersions $(r=0.84$ for oxidized tailings and $r=0.92$ for reduced tailings) (Fig. 3Bh). Separating oxidized (brown) from reduced (gray) tailings, the latter expected to contain higher concentrations of arsenopyrite, did not yield much improvement in the correlation. This suggests that several arsenic minerals are responsible for the variability in As extractability with and without glycine, and with the data that we produced this is not easy to unravel. A more in depth study is required, with several different As minerals, as well as adsorbed As(V) (mainly to Fe oxides), which is expected to be high at low $\mathrm{pH}$, and thus not very BA. In the case of SLP, As speciation is expected to be more homogeneous, mainly as arsenolite $\left(\mathrm{As}_{2} \mathrm{O}_{3}\right)$ (cf. previous section), which shows a very good correlation between BA methods.
In general, $\mathrm{Cu}, \mathrm{Zn}$, and $\mathrm{Pb}$ (in $\mathrm{TX}$ ), show a slightly higher extractability in glycine than in $\mathrm{HCl}$ alone (slopes between 0.92 and 0.95). But $\mathrm{Pb}$ in SLP samples (with low anglesite contents), shows a much higher extractability with this ligand (slope of 0.8 ).

Overall, the correlations obtained in this research are considerably better than those reported in the literature in general, with the exception of the results obtained for $\mathrm{Pb}$ present as anglesite in high proportions, and As in various mineral phases (SantanaSilva 2016) in TX.

\section{CONCLUSIONS}

Metallurgical and mining affected environments were selected to compare the BA SBCR method that uses glycine and $\mathrm{HCl}$ at $\mathrm{pH} 1.5$, with a method using only $\mathrm{HCl}$ also at $\mathrm{pH} 1.5$. Very strong to perfect correlations ( $\mathrm{r}$ from 0.98 to 1 ) between both methods were found for $\mathrm{Tl}, \mathrm{Cd}(\mathrm{II}), \mathrm{Cu}(\mathrm{II})$, and $\mathrm{Zn}(\mathrm{II})$. Also, slopes 
in almost all cases were close to 1, meaning glycine does not show an evident extraction activity. For $\mathrm{Pb}$ extractions perfect correlations were also found but only when the solid matrix does not contain anglesite, which shows a considerably higher solubility in glycine and $\mathrm{HCl}$ than in $\mathrm{HCl}$ alone. Of these elements, $\mathrm{Cu}, \mathrm{Zn}$ and $\mathrm{Pb}$ showed slightly higher solubilities in glycine $+\mathrm{HCl}$ than in $\mathrm{HCl}$ alone, but with no effect on the strong correlation found between methods.

Arsenic was the only problematic species that only shows perfect correlations in the metallurgical zone, where its speciation is more homogeneous due to generalized oxidation to arsenolite $\left(\mathrm{As}_{2} \mathrm{O}_{3}\right)$. A very large variation in the As BA data was obtained for mine tailings, which must be related to a suite of mineralogical associations, in addition to arsenopyrite, abundant in fresh, unoxidized tailings. The three experimental factors imposed that were crucial to obtain such high correlations, and higher than previously reported in the literature for the suite of elements analyzed here were: a rigorous $\mathrm{pH}$ of $1.5 \pm 0.1$ and stirring time of $1 \mathrm{~h} \pm 1 \mathrm{~min}$, as well as the use of filtering membranes of $0.05 \mu \mathrm{m}$ pore size. We recommend that in BA work in general, these conditions, even if chosen at different values (except the pore size of filtering membranes), should be kept as rigorous as possible. Therefore a simple use of $\mathrm{HCl}$ at $\mathrm{pH} 1.5$ is perfectly suitable to determine gastric bioaccessibility in most important PTEs, which can be used to assess risk situations in areas contaminated by the mining and metallurgical industry.

The advantages of excluding glycine from the extraction method can be summarized as the evident lowering of costs brought about not only from not having to acquire this reagent, but also in the total amounts of $\mathrm{HCl}$ added and time consumed in adjusting the $\mathrm{pH}$ to 1.5 . Glycine required final $\mathrm{HCl}$ concentrations between $0.3 \mathrm{M}$ and $0.4 \mathrm{M}$, while in its absence final $\mathrm{HCl}$ concentrations were reduced to between $0.1 \mathrm{M}$ and $0.03 \mathrm{M}$.

\section{ACKNOWLEDGMENTS}

Y. Cruz-Hernández is thankful to the Consejo Nacional de Ciencia y Tecnología (CONACYT) for the fellowship received to accomplish Ph.D. studies. The authors are grateful to the Universidad Nacional Autónoma de México - Programa de Apoyo a Proyectos de Investigación e Innovación Tecnológica (UNAM PAPIIT IG100215), the United States-México UC-MEXUS-CONACyT
CN 15-44 for the financial support to perform this investigation. They also acknowledge the students and technicians of the Environmental Geochemistry Laboratory of the Geology Institute at UNAM for their support and collaboration, especially to Fabiola Vega, Daniel Ramos and Mismel Ruiz. Thanks are also due to Ofelia Morton for the use of the ICP-MS laboratory.

\section{REFERENCES}

Armienta M.A., Talavera O., Morton O. and Barrera M. (2003). Geochemistry of metals from mine tailings in Taxco, Mexico. Bull. Environ. Contam. Toxicol. 71 (2), 387-393. DOI: 10.1007/s00128-003-0176-0

Atkins A.L, Shaw S. and Peacock C.L. (2016). Release of $\mathrm{Ni}$ from birnessite during transformation of birnessite to todorokite: Implications for $\mathrm{Ni}$ cycling in marine sediments. Geochim. Cosmochim. Acta 189, 158-183. DOI: 10.1016/j.gca.2016.06.007

Cao X., Ma L., Li B. and Yang Y. (2009). Immobilization of $\mathrm{Zn}, \mathrm{Cu}$, and $\mathrm{Pb}$ in contaminated soils using phosphate rock and phosphoric acid. J. Hazard. Mater. 164 (2-3), 555-564. DOI: 10.1016/j.jhazmat.2008.08.034

Carrizales L., Razo I., Téllez-Hernández J.I., TorresNerio R., Torres A., Batres L.E., Cubillas A.C. and Díaz-Barriga F. (2006). Exposure to arsenic and lead of children living near a copper-smelter in San Luis Potosi, Mexico: Importance of soil contamination for exposure of children. Environ. Res. 101 (1), 1-10.

DOI: 10.1016/j.envres.2005.07.010

Cruz-Hernández Y., Ruiz-García M., Villalobos M., Romero F., Mesa-Figueroa D., Garrido F., HernándezÁlvarez E. and Pi-Puig T. (2018). Fractionation and mobility of thallium in areas impacted by miningmetallurgical activities: Identification of water-soluble $\mathrm{Tl}(\mathrm{I})$ fraction. Environ. Pollut. 237, 154-165.

DOI: 10.1016/j.envpol.2018.02.031

Cui J., Zhao Y., Shan J., Beiyuan J., Tsang D., Poon Ch., Chan T., Wang W. and Li X. (2018). Speciation, mobilization, and bioaccessibility of arsenic in geogenic soil profile from Hong Kong. Environ. Pollut. 232, 375-384. DOI: 10.1016/j.envpol.2017.09.040

Dodd M., Rasmussen P.E. and Chénier M. (2013). Comparison of two in vitro extraction protocols for assessing metals bioaccessibility using dust and soil reference materials. Human Ecol. Risk Assess. 19 (4), 1014-1027. DOI: 10.1080/10807039.2012.719381

Drexler J.W. and Brattin W.J. (2007). An in vitro procedure for estimation of lead relative bioavailability: With validation. Human Ecol. Risk Assess. 13 (2), 383-401. DOI: $10.1080 / 10807030701226350$ 
EEA (2014). Soil guideline values for cadmium in soil. Science Report SC050021/Cadmium SGV. Bristol European Environmental Agency. European Standard EN 71-33. Brussels, Belgium, 11 pp.

Fujimori T., Taniguchi M., Agusa T., Shiota K., Takaoka M., Yoshida A., Terazono A., Ballesteros F. and Takigami H. (2018). Effect of lead speciation on its oral bioaccessibility in surface dust and soil of electronic-wastes recycling sites. J. Hazard. Mater. 341, 365-372.

DOI: $10.1016 /$ j.jhazmat.2017.07.066

Li H.H., Che LJ., Yu L., Guo Z.B., Shan C.Q., Lin. J.Q., Gu Y.J., Yang Z.B., Yang Y.X., Shao J.R., Zhu X.M. and Cheng Z. (2017). Pollution characteristics and risk assessment of human exposure to oral bioaccessibility of heavy metals via urban street dusts from different functional areas in Chengdu, China. Sci. Total Environ. 586, 1076-1084. DOI: 10.1016/j.scitotenv.2017.02.092

ISO (2005). Soil quality-determination of $\mathrm{pH}$. Method 10390:2005. International Organization for Standardization. Manual. Geneva, Switzerland, 7 pp.

Kim J.Y., Kim K.W., Lee J.U., Lee J.S. and Cook J. (2002). Assessment of As and heavy metal contamination in the vicinity of Duckum AueAg mine, Korea. Environ. Geochem. Health 24, 215-227.

Koch I., Moriarty M., House K., Sui J., Cullen W.R., Saper R.B. and Reimer K.J. (2011). Bioaccessibility of lead and arsenic in traditional Indian medicines. Sci. Total Environ. 409 (21), 4545-4552.

DOI: 10.1016/j.scitotenv.2011.07.059

Laird B.D., Weiseth B., Packull-McCormick S.R., Peak D., Dodd M. and Siciliano S.D. (2015). Solid-liquid separation method governs the in vitro bioaccessibility of metals in contaminated soil-like test materials. Chemosphere 134, 544-549.

DOI: $10.1016 /$ j.chemosphere.2014.12.019

Li J., Li K., Cave M., Li H.B. and Ma L. (2015). Lead bioaccessibility in 12 contaminated soils from China: Correlation to lead relative bioavailability and lead in different fractions. J. Hazard. Mater. 295, 55-62.

DOI: 10.1016/j.jhazmat.2015.03.061

Li P., Qian H., Howard K.W.F., Wu J. and Lyu X. (2014). Anthropogenic pollution and variability of manganese in alluvial sediments of the Yellow River, Ningxia, northwest China. Environ Monit. Assess. 186 (3), 1385-1398. DOI: 10.1007/s10661-013-3461-3

Li P., Qian H., Howard K.W.F. and Wu J. (2015). Heavy metal contamination of Yellow River alluvial sediments, northwest China. Environ. Earth Sci. 73 (7), 3403-3415. DOI: 10.1007/s12665-014-3628-4

Li P., Li X., Meng X., Li M. and Zhang Y. (2016b). Appraising groundwater quality and health risks from contamination in a semiarid region of northwest China.
Exposure and Health 8 (3), 361-379.

DOI: $10.1007 / \mathrm{s} 12403-016-0205-y$

Luo X.S., Yu S., Zhu Y.G. and Li X.D. (2012). Trace metal contamination in urban soils of China. Sci. Total Environ. 421-422, 17-30.

DOI: $10.1016 /$ j.scitotenv.2011.04.020

Madrid F., Biasioli M. and Ajmone-Marsan F. (2008). Availability and bioaccessibility of metals in fine particles of some urban soils. Arch. Environ. Contam. Toxicol. 55 (1), 21-32. DOI: 10.1007/s00244-007-9086-1

Mendoza J., Garrido T., Quilodrán Q., Segovia M. and Parada J. (2017). Evaluation of the bioaccessible gastric and intestinal fractions of heavy metals in contaminated soils by means of a simple bioaccessibility extraction test. Chemosphere 176, 81-88.

DOI: 10.1016/j.chemosphere.2017.02.066

Mingot J., de Miguel E. and Chacón E. (2011). Assessment of oral bioaccessibility of arsenic in playground soil in Madrid (Spain): A three-method comparison and implications for risk assessment. Chemosphere 84 (10), 1386-1391. DOI: 10.1016/j.chemosphere.2011.05.001

Palumbo-Roe B., Wragg J., Cave M.R. and Wagner G. (2013). Effect of weathering product assemblages on $\mathrm{Pb}$ bioaccessibility in mine waste: implications for risk management. Environ. Sci. Pollut. Res. Int. 20 (11), 7699-7710. DOI: 10.1007/s11356-013-1515-2

Peacock C. and Moon E. (2012). Oxidative scavenging of thallium by birnessite: explanation for thallium enrichment and stable isotope fractionation in marine ferromanganese precipitates. Geochem. Cosmochim. Acta 84, 297-313. DOI: 10.1016/j.gca.2012.01.036

Pelfrêne A. and Douay F. (2018). Assessment of oral and lung bioaccessibility of $\mathrm{Cd}$ and $\mathrm{Pb}$ from smelterimpacted dust. Environ. Sci. Poll. Res. 25 (4), 37183730. DOI: $10.1007 /$ s11356-017-0760-1

Peter A. and Viraraghavan T. (2005). Thallium: a review of public health and environmental concerns and environmental concerns. Environ. Int. 31 (4), 493-501. DOI: 10.1016/j.envint.2004.09.003

Pueyo M., Lopez-Sanchez J.F. and Rauret G. (2004). Assessment of $\mathrm{CaCl}_{2}, \mathrm{NaNO}_{3}$ and $\mathrm{NH}_{4} \mathrm{NO}_{3}$ extraction procedures for the study of $\mathrm{Cd}, \mathrm{Cu}, \mathrm{Pb}$ and $\mathrm{Zn}$ extractability in contaminated soils. Anal. Chim. Acta. 504 (2), 217-226. DOI: 10.1016/j.aca.2003.10.047

Rasmussen P.E., Beauchemin S., Nugent M., Dugandzic R., Lanouette M. and Chénier M. (2008). Influence of matrix composition on the bioaccessibility of copper, zinc, and nickel in urban residential dust and soil. Human Ecol. Risk Assess. 14 (2) 351-371. DOI: $10.1080 / 10807030801934960$

Rodrigues S.M., Cruz N., Coelho C., Henriques B., Carvalho L., Duarte A.C., Pereira E. and Römkens P.F.A. (2013). Risk assessment for $\mathrm{Cd}, \mathrm{Cu}, \mathrm{Pb}$ and $\mathrm{Zn}$ in urban 
soils: Chemical availability as the central concept. Environ. Pollut. 183, 234-242.

DOI: $10.1016 /$ j.envpol.2012.10.006

Rollinson H. (1993). Using geochemical data: Evaluation, presentation, interpretation. Longman Scientific and Technical. New York, USA, 352 pp.

Romero F.M. and Gutiérrez R. M. (2010). Estudio comparativo de la peligrosidad de jales en dos zonas mineras localizadas en el sur y centro de México. Bol. Soc. Geol. Mex. 62 (1), 43-53.

Ruby M.V., Davis A., Schoof R., Eberle S. and Sellston C.M. (1996). Estimation of lead and arsenic bioavailability using a physiologically based extraction test. Environ. Sci. Technol. 30 (2), 422-430.

DOI: $10.1021 / \mathrm{es} 950057 \mathrm{z}$

Ruby M.V., Schoof R., Brattin W., Goldade M., Post G., Harnois M., Mosby D.E., Casteel S.W., Berti W., Carpenter M., Edwards D., Cragin D. and Chappell M. (1999). Advances in evaluating the oral bioavailability of inorganics in soil for use in human health risk assessment. Environ. Sci. Technol. 33 (21), 3697-3705. DOI: $10.1021 /$ es $990479 z$

Santana-Silva A. (2016). Diseño y evaluación de un método de extracción simple para determinar la bioaccesibilidad de $\mathrm{As}, \mathrm{Pb}, \mathrm{Cu}, \mathrm{Zn}$ y Cd potencialmente tóxicos en suelos contaminados por residuos minerometalúrgicos. Master Dissertation. Instituto de Geología, Universidad Nacional Autónoma de México. Mexico City, Mexico, 98 pp.

SEMARNAT (2007). Norma Oficial Mexicana NOM-147/ SSA1-2004. Criterios para determinar las concentraciones de remediación de suelos contaminados por arsénico, bario, berilio, cadmio, cromo hexavalente, mercurio, níquel, plata, plomo, selenio, talio y/o vanadio. Secretaría de Medio Ambiente y Recursos Naturales. Diario Oficial de la Federación. Poder Ejecutivo Federal. 2 de marzo de 2007.

Takeda A., Tsukada H., Takaku Y., Hisamatsu S., Inaba J. and Nanzyo M. (2006). Extractability of major and trace elements from agricultural soils using chemical extraction methods: Application for phytoavailability assessment. J. Soil Sci. Plant Nutr. 52 (4), 406-417. DOI: $10.1111 /$ j.1747-0765.2006.00066.x

USEPA (2008). EPA 9200.1-86. Standard Operating Procedure for an In Vitro Bioaccessibility Assay for Lead in Soil. Office of Solid Waste and Emergency Response, United States Environmental Protection Agency. Manual. Washington, D.C., USA, 83 pp.

USEPA (1993). EPA 600/R-93-100. Methods for the determination of inorganic substances in environmental samples. Office of Research and Development, United States Environmental Protection Agency. Manual. Ohio, USA, 127 pp.
Vaca-Escobar K. and Villalobos M. (2015). Modeling the additive effects of $\mathrm{Pb}(\mathrm{II})$ and $\mathrm{Cu}(\mathrm{II})$ on the competitive attenuation of $\mathrm{As}(\mathrm{V})$ through solid precipitation versus adsorption to goethite. Bol. Soc. Geol. Mex. 67(3) 457-465. DOI: 10.18268/BSGM2015v67n3a9

Villalobos M., García-Payne D.G., López-Zepeda J.L., Ceniceros-Gómez A.E. and Gutiérrez-Ruiz M.E. (2010). Natural arsenic attenuation via metal arsenate precipitation in soils contaminated with metallurgical wastes: I. Wet chemical and thermodynamic evidences. Aquat. Geochem. 16 (2), 225-250.

DOI: $10.1007 / \mathrm{s} 10498-009-9065-4$

Villalobos M., Bargar J. and Sposito G. (2005). Mechanisms of $\mathrm{Pb}(\mathrm{II})$ sorption on a biogenic manganese oxide. Environ. Sci. Technol. 39 (2), 569-576.

DOI: 10.1021/es049434a

Villalobos M., Escobar-Quiroz I.N. and Salazar-Camacho C. (2014). The influence of particle size and structure on the sorption and oxidation behavior of birnessite: I. Adsorption of As(V) and oxidation of As(III). Geochim. Cosmochim. Acta 125, 564-581.

DOI: $10.1016 /$ j.gca.2013.10.029

Violante A., Cozzolino V., Perelomov L., Caporale A.G. and Pigna M. (2010). Mobility and bioavailability of heavy metals and metalloids in soil environments. J. Soil. Sci. Plant Nutr. 10 (3), 268-292.

DOI: $10.4067 / \mathrm{S} 0718-95162010000100005$

Voegelin A., Pfenninger N., Petrikis J., Majzlan J., Plötze M., Senn A.C., Mangold S., Steininger R. and Göttlicher J. (2015). Thallium speciation and extractability in a thallium- and arsenic-rich soil developed from mineralized carbonate rock. Environ. Sci. Technol. 49 (9), 5390-5398. DOI: 10.1021/acs.est.5b00629.

Waterlot Ch., Douay F. and Pelfrêne A. (2017). Chemical availability of $\mathrm{Cd}, \mathrm{Pb}$ and $\mathrm{Zn}$ in anthropogenically polluted soil: Assessing the geochemical reactivity and oral bioaccessibility. Pedosphere 27 (3), 616-629. DOI: $10.1016 / \mathrm{S} 1002-0160(17) 60356-4$

Wick S., Baeyens B., Marques Fernandes M. and Voegelin A. (2018). Thallium adsorption onto illite. Environ. Sci. Technol. 52 (2), 571-580.

DOI: $10.1021 /$ acs.est.7b04485

Yang K., Im J., Jeong S. and Nam K. (2015). Determination of human health risk incorporating experimentally derived site-specific bioaccessibility of arsenic at an old abandoned smelter site. Environ. Res. 137, 78-84. DOI: 10.1016/j.envres.2014.11.019

Zong Y.T., Xiao Q. and Lu S.G. (2016). Chemical fraction, leachability, and bioaccessibility of heavy metals in contaminated soils, Northeast China. Environ. Sci. Pollut. Res. Int. 23 (23), 24107-24114. DOI: $10.1007 / \mathrm{s} 11356-016-7598-9$ 


\section{SUPPLEMENTARY INFORMATION}

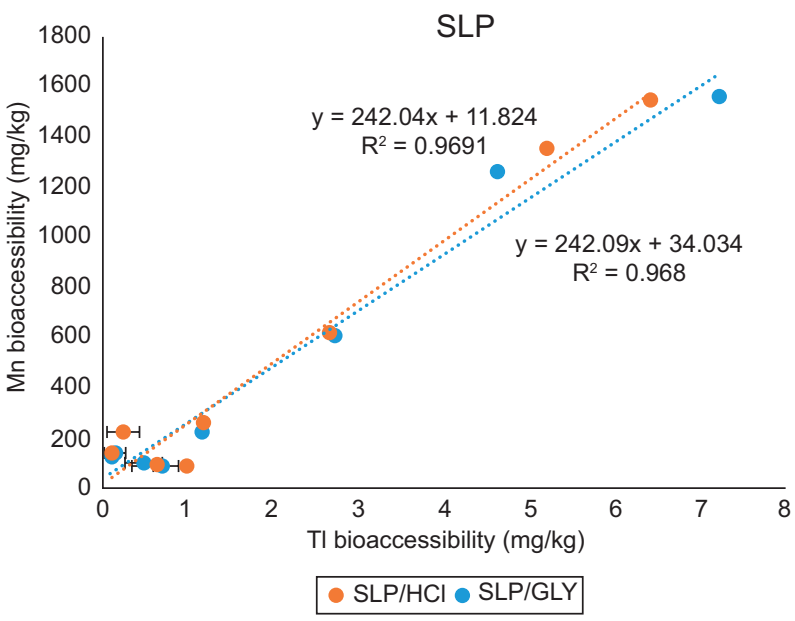

Fig. SI.Comparison of thallium and manganese bioaccessibility (BA) from both tests applied to the samples of San Luis Potosí (SLP). Error bars indicate standard error 
TABLE SI. LOCATION AND DESCRIPTION OF SELECTED SAMPLES

\begin{tabular}{|c|c|c|c|}
\hline Sample & $\begin{array}{c}\text { Coordinates } \\
\text { East }\end{array}$ & $\begin{array}{l}\text { UTM } \\
\text { North }\end{array}$ & Description \\
\hline \multicolumn{4}{|r|}{ Soils from the metallurgical site. } \\
\hline SLP01 & 290700 & 2453698 & Surface soil $(0-5 \mathrm{~cm})$ contaminated by metallurgical waste. From $\mathrm{Cu}$ and As plant. \\
\hline SLP02 & 290751 & 2452152 & Surface soil $(0-5 \mathrm{~cm})$ contaminated by metallurgical waste. From $\mathrm{Cu}$ plant. \\
\hline SLP03 & 291052 & 2451852 & Surface soil $(0-5 \mathrm{~cm})$ contaminated by metallurgical waste. From $\mathrm{Cu}$ plant. \\
\hline SLP04 & 291351 & 2452250 & Surface soil $(0-5 \mathrm{~cm})$ contaminated by metallurgical waste. From As plant. \\
\hline SLP05 & 290652 & 2451450 & Surface soil $(0-5 \mathrm{~cm})$ contaminated by metallurgical waste. From $\mathrm{Cu}$ plant. \\
\hline SLP06 & 290548 & 2451952 & Surface soil $(0-5 \mathrm{~cm})$ contaminated by alkaline metallurgical waste. From $\mathrm{Cu}$ plant. \\
\hline SLP07 & 290749 & 2451749 & Surface soil $(0-5 \mathrm{~cm})$ contaminated by metallurgical waste. From $\mathrm{Cu}$ plant. \\
\hline SLP08 & 291352 & 2451851 & Surface soil $(0-5 \mathrm{~cm})$ contaminated by metallurgical waste. From As plant. \\
\hline SLP09 & 290450 & 2451650 & Metallurgical waste coming from smelting ashes. \\
\hline \multicolumn{4}{|c|}{ Tailings impoundment "La Concha". Homogeneous profile 1 and 2. Brown (oxidized) tailings. } \\
\hline TXP1a & 432884 & 2050175 & $0-5 \mathrm{~cm}$ \\
\hline TXP1b & $*$ & * & $5-50 \mathrm{~cm}$ \\
\hline TXP1c & $*$ & $*$ & $50-100 \mathrm{~cm}$ \\
\hline TXP2a & 432886 & 2050012 & $0-5 \mathrm{~cm}$ \\
\hline TXP2b & * & * & $5-50 \mathrm{~cm}$ \\
\hline TXP2c & * & $*$ & $50-100 \mathrm{~cm}$ \\
\hline \multicolumn{4}{|c|}{ Tailings impoundment "El Fraile”. Heterogeneous profile 3 and 4.} \\
\hline TXP3a & 432807 & 2048351 & $0-30 \mathrm{~cm}$. Filling material \\
\hline TXP3b & $*$ & $*$ & $30-80 \mathrm{~cm}$. Tailings yellow apaque \\
\hline TXP3c & $*$ & $*$ & $80-100 \mathrm{~cm}$. Tailings grays \\
\hline TXP4a & 432876 & 2048455 & $0-40 \mathrm{~cm}$. Filling material \\
\hline TXP4b & $*$ & $*$ & $40-180 \mathrm{~cm}$. Tailings yellow opaque \\
\hline TXP4c & $*$ & $*$ & $180-200 \mathrm{~cm}$. Tailings grays \\
\hline \multicolumn{4}{|c|}{ Tailings impoundment "Foster". Homogeneous profile 5 and 6. Gray (fresh-reduced) tailings. } \\
\hline TXP5a & 436966 & 2048702 & $0-5 \mathrm{~cm}$ \\
\hline TXP5b & * & * & $5-50 \mathrm{~cm}$ \\
\hline TXP5c & * & * & $50-100 \mathrm{~cm}$ \\
\hline TXP6а & 436987 & 2048102 & $0-5 \mathrm{~cm}$ \\
\hline TXP6b & * & * & $5-50 \mathrm{~cm}$ \\
\hline TXP6c & * & $*$ & $50-100 \mathrm{~cm}$ \\
\hline \multicolumn{4}{|c|}{ Soils samples near "La Concha" Tailings impoundment. } \\
\hline TXSC1 & 432929 & 2050013 & Sample soil near a river. $0-5 \mathrm{~cm}$ \\
\hline TXSC2 & 432975 & 2050103 & Sample soil near a river. $0-5 \mathrm{~cm}$ \\
\hline \multicolumn{4}{|c|}{ Soils samples near "El Fraile" Tailings impoundment. } \\
\hline TXSF1 & 433327 & 2048463 & Sample soil near a river. $0-5 \mathrm{~cm}$. There is a lot of vegetation. \\
\hline TXSF2 & 433379 & 2048371 & Sample soil near a river. $0-5 \mathrm{~cm}$. There is a lot of vegetation. \\
\hline
\end{tabular}

*The coordinates given correspond to profile 
TABLE SII. MINERALOGICAL COMPOSITION OF THE SAMPLES (BASED ON THE SEMI-QUANTITATIVE X RAY DIFFRACTION ANALYSIS) COLLECTED FROM SAN LUIS POTOSÍ (SLP) AND TAXCO (TX)

\begin{tabular}{|c|c|c|c|c|c|c|c|c|c|c|c|c|c|c|c|c|c|}
\hline \multirow{2}{*}{ Sample } & \multicolumn{17}{|c|}{ Identified mineral phases and semi-quantitative analysis } \\
\hline & Ars & Ang & $\mathrm{Cal}$ & Dol & Fsp & Gth & $\mathrm{Gp}$ & Hem & Jrs & Mca & Mim & PI & Px & Py & Qz & Smi & Zeo \\
\hline SLP01 & I & + & & & ++++ & + & & + & & + & & ++++ & & & ++++ & & \\
\hline SLP02 & ++ & I & & & ++++ & $\mathrm{I}$ & & + & & + & & ++++ & & & ++++ & & \\
\hline SLP03 & + & + & & & ++++ & + & & I & ++ & + & & +++ & & & ++++ & & \\
\hline SLP04 & I & ++ & & & ++++ & + & & + & & + & & ++++ & & + & ++++ & & \\
\hline SLP05 & & + & + & & ++++ & + & & + & & +++ & & +++ & & & ++++ & & \\
\hline SLP06 & +++ & ++ & ++ & & +++ & I & & + & & + & & ++++ & & + & ++++ & & \\
\hline SLP07 & ++ & + & & & ++++ & + & & I & + & + & & ++++ & & & ++++ & & \\
\hline SLP08 & + & + & ++ & & ++++ & + & & + & & & & ++++ & & + & ++++ & & \\
\hline SLP09 & ++++ & +++ & & & I & + & +++ & + & & & & ++++ & & & ++++ & & +++++ \\
\hline TXP1a & & + & +++ & ++ & ++++ & + & & & ++ & & + & & & & ++++ & ++ & \\
\hline TXP1b & & + & +++ & +++ & +++ & + & & & ++ & & + & & & & ++++ & ++ & \\
\hline TXP1c & & & ++++ & ++ & +++ & + & & & ++ & & + & & & & ++++ & ++ & \\
\hline TXP2a & & & ++++ & ++ & ++++ & + & ++ & & ++ & & I & & & & ++++ & ++ & \\
\hline TXP2b & & + & ++++ & ++ & ++++ & + & I & & ++ & & + & & & & ++++ & ++ & \\
\hline TXP2c & & & ++++ & ++ & ++++ & + & I & & ++ & & + & & & & ++++ & ++ & \\
\hline TXP3a & & & ++++ & & I & & I & & I & +++ & & +++ & & I & ++++ & & \\
\hline TXP3b & & & I & & ++ & & ++++ & & ++ & + & & I & & + & ++++ & & \\
\hline TXP3c & & I & I & & ++ & & ++++ & & + & + & & I & & + & ++++ & & \\
\hline TXP4a & & I & +++ & & I & & ++ & & I & ++++ & & +++ & & & ++++ & & \\
\hline TXP4b & & & I & & +++ & & I & & ++ & ++ & & & & & +++++ & & \\
\hline TXP4c & & & + & & ++ & & ++ & & I & ++ & & & & & +++++ & & \\
\hline ТХP5a & & & ++++ & & & & + & & & ++ & I & & +++ & + & ++++ & & \\
\hline TXP5b & & & ++++ & & & & + & & & ++ & I & & +++ & + & ++++ & & \\
\hline TXP5c & & & ++++ & & & & I & & & ++ & ++ & & +++ & ++ & ++++ & & \\
\hline TXP6а & & & +++ & & & & + & & & ++ & & & +++ & +++ & ++++ & & \\
\hline TXP6b & & & ++++ & & & & I & & & ++ & & & +++ & +++ & ++++ & & \\
\hline ТXР6c & & & ++++ & & & & I & & & ++ & & & +++ & +++ & ++++ & & \\
\hline TXSC1 & & + & ++ & ++ & & & & & & & & ++ & & & +++++ & & \\
\hline TXSC2 & & + & + & & & & & & & ++ & & ++ & & & +++++ & & \\
\hline TXSF1 & & + & & & ++++ & & I & & ++ & ++ & & & & & ++++ & & \\
\hline TXSF2 & & + & & & ++++ & & + & & + & ++ & & & & & ++++ & & \\
\hline
\end{tabular}

+++++ major component $(>50 \%)$; ++++ $(20-50 \%) ;+++(10-20 \%) ;++(5-10 \%) ;+(1-5 \%)$; I (identifiable traces).

Ars: Arsenolite $\left(\mathrm{As}_{2} \mathrm{O}_{3}\right)$; Ang: Anglesite $\left(\mathrm{PbSO}_{4}\right)$; Cal: calcite $\left(\mathrm{Ca}\left(\mathrm{CO}_{3}\right)_{2}\right)$; Dol: Dolomite $\left(\mathrm{CaMg}_{2}\left(\mathrm{CO}_{3}\right)_{2}\right)$; Fsp: feldspar $\left(\mathrm{KAlSi}_{3} \mathrm{O}_{8}\right.$ (orthoclase) - $\mathrm{NaAlSi}_{3} \mathrm{O}_{8}$ (Albite) - $\left.\mathrm{CaAl}_{2} \mathrm{Si}_{2} \mathrm{O}_{8}\right)$; Gth: goethite [FeO(OH)]; Gp: Gypsum $\left(\mathrm{CaSO}_{4}{ }^{*} 2 \mathrm{H}_{2} \mathrm{O}\right)$; Hem: hematite $\left(\mathrm{Fe}_{2} \mathrm{O}_{3}\right)$; Jrs: jarosite $\left(\mathrm{KFe}_{3}{ }^{+3}(\mathrm{OH})_{6}\left(\mathrm{SO}_{4}\right)_{2}\right)$; Mca: Mica $\left(\mathrm{Al} \mathrm{Si}{ }_{3} \mathrm{O}_{10} \mathrm{~A}_{12}(\mathrm{Mg} \text {. Fe })_{3}(\mathrm{OH})_{2} \mathrm{~K}\right)$; Mim: Mimetite $\left(\mathrm{Pb}_{5}\left(\mathrm{AsO}_{4}\right)_{3} \mathrm{Cl}\right)$; Po: pyrrhotite; Py: pyrite (FeS2); PI: plagioclase [( $\left.\mathrm{Na}, \mathrm{Ca})(\mathrm{Si}, \mathrm{Al})_{3} \mathrm{O}_{8}\right]$; Px: Pyroxene $\left(\mathrm{MgCaSi}_{2} \mathrm{O}_{6}\right)$; Qz: quartz $\left(\mathrm{SiO}_{2}\right) ; \mathrm{Smi}$ : Smithsonite $\left(\mathrm{ZnCO}_{3}\right) ; \mathrm{Zeo}$ : Zeolite $\left((\mathrm{Ca}, \mathrm{Na})_{2}-3 \mathrm{Al}_{3}\left(\mathrm{Al}, \mathrm{Si}_{2}\right)_{2} \mathrm{Si}_{13} \mathrm{O}_{36} \cdot 12 \mathrm{H}_{2} \mathrm{O}\right)$. To discriminate between illite and mica, the peaks appearing at approximately $10 \mathrm{~A}^{\mathrm{o}}$ were analyzed and assigned to mica when narrow, and to illite when broad 
TABLE SIII. BIOACCESSIBILITY (BA) OF Mn IN THE SAN LUIS POTOSÍ (SLP) AREA

Mn bioaccessible content $(\mathrm{mg} / \mathrm{kg})$

\begin{tabular}{lcccc}
\hline Samples & $\begin{array}{c}\text { Concentrations extracted in } \\
\text { hydrochloric acid }+ \text { glycine }\end{array}$ & $\%$ & $\begin{array}{c}\text { Concentrations extracted } \\
\text { in hydrochloric acid }\end{array}$ & $\%$ \\
\hline SLP01 & 222 & 41.1 & 139 & 25.8 \\
SLP02 & 89.6 & 17.2 & 83.6 & 16.1 \\
SLP03 & 140 & 33.4 & 129 & 30.6 \\
SLP04 & 260 & 19.4 & 230 & 17.1 \\
SLP05 & 91.7 & 15.3 & 99.0 & 16.5 \\
SLP06 & $1.54 \times 10^{3}$ & 29.7 & $1.56 \times 10^{3}$ & 29.9 \\
SLP07 & 615 & 34.1 & 608 & 33.8 \\
SLP08 & $1.35 \times 10^{3}$ & 96.6 & $1.27 \times 10^{3}$ & 90.1 \\
SLP09 & 141 & 53.8 & 132 & 50.8 \\
\hline
\end{tabular}

